\title{
Initial Investigation of the Acoustics of a Counter- Rotating Open Rotor Model With Historical Baseline Blades in a Low-Speed Wind Tunnel
}

David M. Elliott

Glenn Research Center, Cleveland, Ohio 


\section{NASA STI Program . . . in Profile}

Since its founding, NASA has been dedicated to the advancement of aeronautics and space science. The NASA Scientific and Technical Information (STI) program plays a key part in helping NASA maintain this important role.

The NASA STI Program operates under the auspices of the Agency Chief Information Officer. It collects, organizes, provides for archiving, and disseminates NASA's STI. The NASA STI program provides access to the NASA Aeronautics and Space Database and its public interface, the NASA Technical Reports Server, thus providing one of the largest collections of aeronautical and space science STI in the world. Results are published in both non-NASA channels and by NASA in the NASA STI Report Series, which includes the following report types:

- TECHNICAL PUBLICATION. Reports of completed research or a major significant phase of research that present the results of NASA programs and include extensive data or theoretical analysis. Includes compilations of significant scientific and technical data and information deemed to be of continuing reference value. NASA counterpart of peer-reviewed formal professional papers but has less stringent limitations on manuscript length and extent of graphic presentations.

- TECHNICAL MEMORANDUM. Scientific and technical findings that are preliminary or of specialized interest, e.g., quick release reports, working papers, and bibliographies that contain minimal annotation. Does not contain extensive analysis.

- CONTRACTOR REPORT. Scientific and technical findings by NASA-sponsored contractors and grantees.
- CONFERENCE PUBLICATION. Collected papers from scientific and technical conferences, symposia, seminars, or other meetings sponsored or cosponsored by NASA.

- SPECIAL PUBLICATION. Scientific, technical, or historical information from NASA programs, projects, and missions, often concerned with subjects having substantial public interest.

- TECHNICAL TRANSLATION. Englishlanguage translations of foreign scientific and technical material pertinent to NASA's mission.

Specialized services also include creating custom thesauri, building customized databases, organizing and publishing research results.

For more information about the NASA STI program, see the following:

- Access the NASA STI program home page at http://www.sti.nasa.gov

- E-mail your question via the Internet to help@ sti.nasa.gov

- Fax your question to the NASA STI Help Desk at $443-757-5803$

- Telephone the NASA STI Help Desk at 443-757-5802

- Write to: NASA Center for AeroSpace Information (CASI) 7115 Standard Drive Hanover, MD 21076-1320 


\section{Initial Investigation of the Acoustics of a Counter- Rotating Open Rotor Model With Historical Baseline Blades in a Low-Speed Wind Tunnel}

David M. Elliott

Glenn Research Center, Cleveland, Ohio

Prepared for the

17th Aeroacoustics Conference

cosponsored by the American Institute of Aeronautics and Astronautics and the Confederation of European Aerospace Societies

Portland, Oregon, June 5-8, 2011

National Aeronautics and

Space Administration

Glenn Research Center

Cleveland, Ohio 44135 


\section{Acknowledgments}

The NASA Environmentally Responsible Aviation Project provided funding for testing support while the NASA Subsonic Fixed Wing Project provided funding for analysis support.

Trade names and trademarks are used in this report for identification only. Their usage does not constitute an official endorsement, either expressed or implied, by the National Aeronautics and Space Administration.

This work was sponsored by the Fundamental Aeronautics Program at the NASA Glenn Research Center.

Level of Review: This material has been technically reviewed by technical management.

Available from

NASA Center for Aerospace Information 7115 Standard Drive

Hanover, MD 21076-1320
National Technical Information Service 5301 Shawnee Road Alexandria, VA 22312 


\title{
Initial Investigation of the Acoustics of a Counter- Rotating Open Rotor Model With Historical Baseline Blades in a Low-Speed Wind Tunnel
}

\author{
David M. Elliott \\ National Aeronautics and Space Administration \\ Glenn Research Center \\ Cleveland, Ohio 44135
}

\begin{abstract}
A counter-rotating open rotor scale model was tested in the NASA Glenn Research Center 9- by 15-Foot Low-Speed Wind Tunnel (LSWT). This model used a historical baseline blade set with which modern blade designs will be compared against on an acoustic and aerodynamic performance basis. Different blade pitch angles simulating approach and takeoff conditions were tested, along with angle-ofattack configurations. A configuration was also tested in order to determine the acoustic effects of a pylon. The shaft speed was varied for each configuration in order to get data over a range of operability. The freestream Mach number was also varied for some configurations. Sideline acoustic data were taken for each of these test configurations.
\end{abstract}

\section{Nomenclature}

$\begin{array}{ll}\text { ORPR } & \text { Open Rotor Propulsion Rig } \\ \text { OAPWL } & \text { Overall Power Level } \\ \text { BPF } & \text { Blade Passage Frequency } \\ \text { OASPL } & \text { Overall Sound Pressure Level } \\ \text { SPL } & \text { Sound Pressure Level } \\ \text { PSD } & \text { Power Spectral Density } \\ \text { LSWT } & \text { Low Speed Wind Tunnel } \\ \text { AOA } & \text { Angle of Attack }\end{array}$

\section{Introduction}

Counter-rotating open rotor models were tested at the NASA Glenn Research Center in the 1980's and early 1990's (Refs. 1 and 2). At that time, the fuel consumption advantage of open rotors was not great enough to overcome their other shortcomings compared to ducted fans. One of the primary shortcomings was noise output. Due to the increasing cost of fuel in recent years, there is a renewed interest in open rotor propulsion systems. Fortunately, there are new improved technologies and tools available, which can be applied to the design of open rotors, which will help mitigate their disadvantages. NASA is again investigating the counter-rotating open rotor to determine if it is a viable propulsion system for future aircraft. In partnership with General Electric Aviation, the NASA Glenn Research Center started a test program to test advanced blade sets on the scale Open Rotor Propulsion Rig (ORPR). This rig was tested in the NASA Glenn Research Center 9- by 15-Foot Low-Speed Wind Tunnel (LSWT) in order to get acoustic and aerodynamic performance data. This paper focuses on the acoustic data acquired during the NASA portion of the test (Ref. 3), which was funded by the Environmentally Responsible Aviation Project. The main goal of this part of the overall test campaign was to acquire data on a so-called historical baseline blade set. The historical baseline blade set is representative of late 1980's state of the art, when open rotor systems were last tested on a wide scale. This blade set concentrated on aerodynamic performance as opposed to acoustic noise reduction. Advanced blade sets 
will be compared against the historical baseline blades to determine if there are any acoustic or aerodynamic improvements. The historical baseline blade data is also used to validate prediction models for counter-rotation open rotor simulations.

\section{Test Hardware}

The ORPR was the same drive system that had been used in previous testing. It was refurbished for this and future tests. The ORPR model is of the pusher type wherein the rotors are located toward the back of the turbomachinery. Turbines within the drive rig are fed by a $450 \mathrm{lb} / \mathrm{in} .{ }^{2}$ air source, which turns the rotor blades. The drive rig is also mounted on a turntable, which provides angle of attack (AOA) testing capability. The capability to simulate a pylon was also designed and installed in some configurations. The blades in the historical baseline set, also designated F31/A31, are approximately $25.7 \mathrm{in}$. in diameter for the forward rotor and $24.8 \mathrm{in}$. in diameter for the aft rotor. The forward rotor has 12 blades and the aft rotor has 10 blades. The pitch of the blades could be adjusted to provide different operational conditions. Two pitch angle configurations were tested during this entry corresponding to takeoff and approach power conditions. The takeoff configuration had pitch angles of $40.1^{\circ}$ for the forward rotor and $40.8^{\circ}$ for the aft rotor. The approach configuration had pitch angles of $33.5^{\circ}$ for the forward rotor and $35.7^{\circ}$ for the aft rotor. The pitch angles were measured at a radius of 9.6 in. These pitch angles were chosen in order to give the best aerodynamic performance at a given shaft speed and flight condition of interest while allowing the rotor torque split to be equal. For this entry, all test points matched forward and aft rotor shaft speed. A photograph of the blades is shown in Figure 1. The installation of the model and drive rig in the 9- by 15-Foot Low-Speed Wind Tunnel is shown in Figures 2 and 3 . Figure 3 also shows the installed pylon hardware.

\section{Test Matrix}

The test matrix reported here consisted of four separate configurations. These configurations included two runs at takeoff blade pitch angle and two runs at approach blade pitch angle. Each blade pitch angle was run with and without the pylon. For a subset of speeds, data for additional angles of attack of $3^{\circ}$ and $8^{\circ}$ were obtained. The majority of the test runs were at a wind tunnel freestream Mach number of 0.2 , however for three of the four runs data was also obtained at the tunnel Mach number of 0.22. Data were acquired at corrected model speeds from 70.7 to 114.4 percent of design. This corresponds to corrected shaft speeds of 4628 to $7487 \mathrm{rpm}$. The test matrix is summarized in Table 1. During this portion of the test, rotors were run at equal speeds.

\section{Test Facility}

This test was conducted in the NASA Glenn Research Center 9- by 15-Foot Low-Speed Wind Tunnel (Refs. 4 to 6). The 9- by 15-Foot Low-Speed Wind Tunnel has acoustically treated walls using Kevlar batting. The maximum flow velocity is approximately 0.22 to 0.23 Mach.

\section{Sideline Acoustics}

Sideline acoustic measurements were obtained using a traversing microphone probe on a track parallel to the fan axis and 60 in. away from it. Data were taken at 18 positions on the traverse at $7.5^{\circ}$ intervals ranging from $17.8^{\circ}$ to $140.6^{\circ}$ relative to the rear rotor pitch change axis with zero reference upstream. The microphone used was $1 / 4$-in. in diameter and a nose cone was installed for in-flow measurements. Data were taken at a sampling rate of $200 \mathrm{kHz}$ in order to ensure a frequency upper limit of at least $60 \mathrm{kHz}$. This would permit scaling this data to full-scale for system analysis purposes.

Corrections to the data have been made for microphone response, bullet nose receptivity, atmospheric 
attenuation, and spherical spreading. All far-field data shown are corrected to 1-ft lossless distance. The accuracy of the data system is $\pm 1 \mathrm{~dB}$. The traversing microphone probe installed in the 9- by 15-Foot Low-Speed Wind Tunnel is shown in Figure 3. The 18 traversing microphone stops and corresponding measured angles relative to the rear rotor pitch change axis are listed in Table 2. Note that the traversing microphone starts in the aft position and moves forward during a test.

\section{Results}

\section{Sideline Acoustic Results}

\section{Representative Spectra}

It is useful to look at a sample spectrum to get an idea of what the noise signature of the counter-rotating open rotor is. Figure 4 shows the spectrum of the historical baseline blades at 6450 corrected rpm using the takeoff pitch setting and with the microphone at $141^{\circ}$ relative to the rear pitch change axis. The large tonal content can be seen from 0 to $20 \mathrm{kHz}$ with the majority in the 0 to $10 \mathrm{kHz}$ range. This is much different from counter-rotating open rotors with equal blade count. From $20 \mathrm{kHz}$ and higher, broadband noise is dominant but drops off steadily. This shows that it is important to focus on the noise below $20 \mathrm{kHz}$ as far as tonal content is concerned. Figure 5 shows the same condition as Figure 4, but now the frequency range has been narrowed from 0 to $10 \mathrm{kHz}$ in order to better illustrate the significant tonal content. Tones are present over this entire frequency range. Figure 6 shows this same spectra zoomed in further from 0 to $5 \mathrm{kHz}$. Here the blade passage and interaction tones are individually labeled. The subscript letter "f" after BPF is for the forward rotor and likewise the "a" is for the aft rotor. While the fundamental front and aft rotor blade passage tones are relatively high, on the order of $20 \mathrm{~dB}$ above broadband, their higher harmonics are much lower, less than $10 \mathrm{~dB}$ above broadband. The highest tone present is the interaction tone $\mathrm{BPF}_{\mathrm{f}}+2 \mathrm{BPF}_{\mathrm{a}}$ which is approximately $25 \mathrm{~dB}$ higher than broadband level. The other interaction tones $2 \mathrm{BPF}_{\mathrm{f}}+\mathrm{BPF}_{\mathrm{a}}$ and $\mathrm{BPF}_{\mathrm{f}}+3 \mathrm{BPF}_{\mathrm{a}}$ are as high as $\mathrm{BPF}_{\mathrm{a}} \cdot \mathrm{BPF}_{\mathrm{f}}+\mathrm{BPF}_{\mathrm{a}}$ and $2 \mathrm{BPF}_{\mathrm{f}}+2 \mathrm{BPF}_{\mathrm{a}}$ are at least $15 \mathrm{~dB}$ higher than broadband levels. This illustrates the interaction tone dominance that is a feature of open rotors with nonequal blade counts at approach and takeoff conditions. Since one-third octave filters are commonly used in acoustic data reduction, a one third-octave band spectrum from 0 to $20 \mathrm{kHz}$ of the data in Figure 4 is shown in Figure 7. This one-third octave spectrum focuses on the fact that the majority of the tonal energy is contained within the bands that make up the 2000 to $4000 \mathrm{~Hz}$ range.

\section{Directivity}

Figure 8 shows noise spectra at directivity angles of $45^{\circ}, 90^{\circ}$, and $141^{\circ}$ for the takeoff pitch angle and 6450 corrected rpm. In terms of broadband content, the $90^{\circ}$ spectrum is the lowest while the $141^{\circ}$ spectrum is on the order of $2 \mathrm{~dB}$ higher over most of the frequency range. The $45^{\circ}$ spectrum is similar in broadband to the $141^{\circ}$ spectrum until about $4 \mathrm{kHz}$ where it drops to $90^{\circ}$ spectrum level. When considering tones, it is difficult to glean a definitive trend due to the significant variability of tone levels in the spectra for the three different angles. Figure 9 shows the data for the approach pitch angle and 5598 corrected rpm. At this forward angle, once again the $90^{\circ}$ spectrum shows the lowest broadband, but now the $45^{\circ}$ spectrum is higher than the $141^{\circ}$ spectrum for frequencies up to $10 \mathrm{kHz}$ where the two spectral levels converge. Below $10 \mathrm{kHz}$ the difference between broadband levels is on the order of $2 \mathrm{~dB}$. The $141^{\circ}$ spectrum appears to have greater tonal content than the spectra at the other two angles for this lower speed condition. While individual spectra can be a useful tool for examining detailed noise, it is beneficial to look at the directivity of overall sound pressure level. These data are shown in Figure 10 for the takeoff and approach pitch angles. When calculating OASPL, the frequency range from $500 \mathrm{~Hz}$ to $50 \mathrm{kHz}$ was used in order to include the lowest blade passage tones while staying above the wind tunnel's anechoic lower limit. It can be seen in Figure 10 that the takeoff pitch angle OASPL is, on average, $15 \mathrm{~dB}$ higher than that for the approach pitch. The directivity shape for the approach pitch angle shows that the OASPL 
is higher at the lowest and highest directivity angles and dipping in the middle. In fact, the highest OASPL is at the forward most angles for approach blade pitch, approximately $8 \mathrm{~dB}$ as compared to broad angles. The OASPL for takeoff pitch angle shows much less of a variance between upstream and downstream angles as compared to broadside angles, only 2 to $3 \mathrm{~dB}$. The inset of Figure 10 shows a plan view of the ORPR with the reference of the directivity angles. Figure 11 shows the directivity for the highest interaction tone seen in Figure 6, the $\mathrm{BPF}_{\mathrm{f}}+2 \mathrm{BPF}_{\mathrm{a}}$ tone. For this tone there is a much higher variability at takeoff than approach. The variability at takeoff is approximately $\pm 10 \mathrm{~dB}$ while approach is only $\pm 5 \mathrm{~dB}$.

\section{Shaft Speed and Blade Pitch Angle}

Examining how the open rotor blades behave at different shaft speeds is useful since this will show noise output over an operating speed line. The shaft speed is also related to blade pitch angle since blade pitch needs to be optimally set for a given shaft speed in order to provide maximum aerodynamic performance. Due to time limitations, it was not possible to obtain more than the two blade pitch angles shown in the test matrix, but these two pitch angles can be compared over the speed range for which data were obtained for them. Figure 12 shows overall acoustic power levels as a function of rpm for the takeoff and approach pitch angles. The design points are shown at the upper end of the takeoff pitch curve and the lower end of the approach pitch curve. The level difference between these conditions is approximately $16 \mathrm{~dB}$. While the curves have very similar slopes, since the approach curve lies to the right of the takeoff, it has a lower overall acoustic power level for any given shaft speed.

The spectra in Figures 13 and 14 show the progression up the speed line for the takeoff pitch angle for the $141^{\circ}$ and $45^{\circ}$ directivity angles, respectively. At $141^{\circ}$, increasing speed approximately $1000 \mathrm{rpm}$ raises broadband noise level by about $10 \mathrm{~dB}$. This is also true at $45^{\circ}$ for the higher speeds, but somewhat less for the lower speed change, on the order of $7 \mathrm{~dB}$. It is also interesting to examine how the pitch angle affects the spectrum at approximately the same shaft speed. The closest shaft speed match for the takeoff and approach pitch angles is 6316 and 6325 rpm respectively. Figures 15 and 16 show the spectra comparisons for different pitch angles at these shaft speeds for $141^{\circ}$ and $45^{\circ}$. At $141^{\circ}$ directivity, the broadband is higher for the takeoff pitch by about $13 \mathrm{~dB}$. It is interesting to note that the tones are somewhat higher relative to broadband levels for the approach pitch angle. The same results appear at the $45^{\circ}$ angle although the amount of tonal content is somewhat less for the approach pitch angle.

\section{Angle of Attack}

The variance in angle of attack was also examined. Figure 17 shows how the overall power levels change with speed for three angles of attack at the takeoff blade pitch angle. There is a small difference between $0^{\circ}$ and $3^{\circ}$, particularly close to the design condition at higher speeds. The $8^{\circ}$ angle of attack level is 2 to $3 \mathrm{~dB}$ higher over the entire speed range. Figure 18 shows this same type of data for the approach

pitch angle. Once again, the level for the $3^{\circ}$ angle of attack does not vary much compared with the $0^{\circ}$ level while the $8^{\circ}$ level is $2 \mathrm{~dB}$ higher over the speed lines. Example spectra for the angle of attack variations at takeoff blade pitch angle are shown in Figures 19 and 20 for $141^{\circ}$ and $45^{\circ}$ directivity, respectively. These spectra are for the corrected shaft speed of $6316 \mathrm{rpm}$, since this speed was one of the few cases for which data was acquired for all three angles of attack. The increase in broadband noise is clearly seen as angle of attack is increased. It appears that there is more tonal content at $8^{\circ}$ angle of attack relative to the $0^{\circ}$ and $3^{\circ}$ cases. 


\section{Freestream Mach Number}

Some limited data were obtained for a freestream wind tunnel Mach number of 0.22 as opposed to 0.2 . This 0.22 Mach number was closer to actual flight conditions. As seen in the test matrix speeds, the corrected shaft speed was adjusted to correspond to the higher Mach number condition. Figure 21 compares overall sound power levels for the speed lines of the two different Mach numbers using the takeoff pitch angle. At the lower speed where the rotors are off condition, freestream Mach number conditions have the same overall power levels. At higher speeds where the rotors are closer to design condition, the higher freestream Mach number of 0.22 produces lower power levels by about $1.5 \mathrm{~dB}$. Figure 22, which plots the same data for the approach pitch angle, shows the higher Mach number of 0.22 produces overall power levels which are lower by approximately $1 \mathrm{~dB}$. The spectral plots of Figures 23 and 24 show the difference in freestream Mach numbers for the $141^{\circ}$ and $45^{\circ}$ directivity angles using the approach pitch angle, where the larger difference was seen in the power levels. The shaft speeds are $6773 \mathrm{rpm}$ for Mach 0.2 and $6617 \mathrm{rpm}$ for Mach 0.22 . The $141^{\circ}$ spectrum shows the lower broadband level occurring at $5000 \mathrm{~Hz}$ and up. In contrast, there is little difference for the $45^{\circ}$ spectrum. These results suggest that most of the reduction in the higher Mach number occurs in the aft directivity area.

\section{Pylon Effects}

Some very important data were acquired with a simulated pylon installed upstream of the rotor blades. It is important to determine what effects the pylon has on the extra noise produced due to the ingestion of the pylon wakes by the rotors, especially the front rotor. This should better represent the noise generated by the counter rotating open rotor when in an actual installed pusher configuration. Figure 25 compares overall acoustic power levels as a function of shaft speed at the takeoff pitch angle for isolated and pylon configurations. At the higher speeds, including those close to design condition, the pylon introduces a low level of extra noise. For example, at the highest speed this is only $0.5 \mathrm{~dB}$. At further off design conditions corresponding to lower speeds, the pylon produces higher power levels, on the order of $3 \mathrm{~dB}$. Figure 26 compares these power levels for the approach pitch angle. Here the overall trend is similar in that the pylon produces less noise as the shaft speed approaches the design value. However in this instance the pylon produces more noise levels at and close to design condition compared with the takeoff condition. In fact the power levels produced by the pylon are 3 to $4 \mathrm{~dB}$ higher in the low speed conditions. Flow field measurements may help determine why the lower speeds are more affected by pylon noise. These measurements could show if the pylon wakes decay faster or are more modest at higher speeds. These results are once again examined by looking at spectra. Figures 27 and 28 show the $141^{\circ}$ and $45^{\circ}$ spectra at the takeoff pitch angle and $6450 \mathrm{rpm}$ speed for isolated and pylon configurations. As expected, there is not a great deal of difference in these spectral levels since this is a high-speed condition. The pylon does appear to produce more tonal content at $45^{\circ}$ in the 1 to $4 \mathrm{kHz}$ range, however, other frequency ranges show little tonal differences. The broadband levels are also very similar. Figures 29 and 30 show the $141^{\circ}$ and $45^{\circ}$ spectra at the approach pitch angle and $5598 \mathrm{rpm}$ speed for isolated and pylon configurations. As is expected, there are larger differences seen in these spectra as compared to the takeoff condition. Lower broadband levels are evident at both $141^{\circ}$ and $45^{\circ}$ and this difference is on the order of 1 to $2 \mathrm{~dB}$. Tonal content also appears to be slightly greater for the pylon configuration for both angles. Clearly, more research is warranted to better understand the effect of the pylon for various blade settings and power conditions.

\section{Conclusion}

The extensive acoustic data obtained for the historical baseline open rotor blade set can be used to benchmark future advanced blade designs on the basis of noise and aerodynamic performance. The historical blade set, owing to its non-equal blade counts, indicates the dominance of interaction tones relative to the individual rotor tones. In general, the historical baseline blade set tends to radiate more 
overall acoustic power levels to the upstream and downstream angles compared with the broad side angles. This noise directivity feature is more pronounced at the approach pitch angle. Noise power levels also increase steadily as shaft speed is increased. Shaft speed and blade pitch angles are interrelated and the takeoff pitch angle has higher noise levels for a given rpm than the approach pitch angle. Angle of attack also affects the noise output. Angles of attack up to $3^{\circ}$ has little effect on the noise power levels, while an angle of attack of $8^{\circ}$ produces a substantial increase on the order of 2 to $3 \mathrm{~dB}$. Testing at a freestream Mach number of 0.22 instead of 0.2 , and adjusting rpm accordingly shows a reduction of the noise power levels by approximately $1 \mathrm{~dB}$. Spectra tend to show that most of the benefit of the higher freestream Mach number occurs in the aft directivity angles. The addition of a pylon increases the noise level and this is more so at lower speeds than higher speeds. The increase in noise due to the pylon at the takeoff condition is less than $1 \mathrm{~dB}$. However at the approach condition the pylon noise increase is as much as $4 \mathrm{~dB}$. Other measurement techniques such as flow field particle imaging velocimetry, when used in conjunction with this acoustic data, could help explain the causes of some of the phenomenon observed in this test. Future blade designs can utilize the results of this data by concentrating efforts to reduce noise of open rotors.

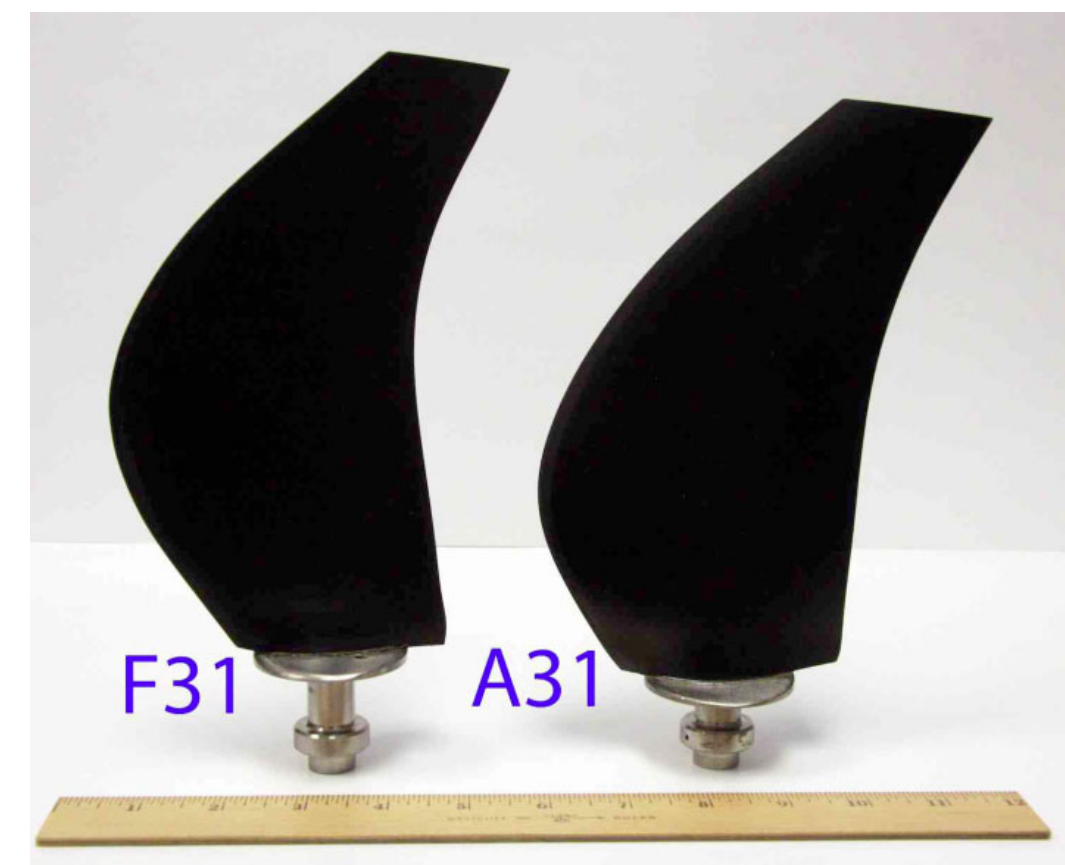

Figure 1.-The historical baseline blades used in the open rotor propulsion rig. 


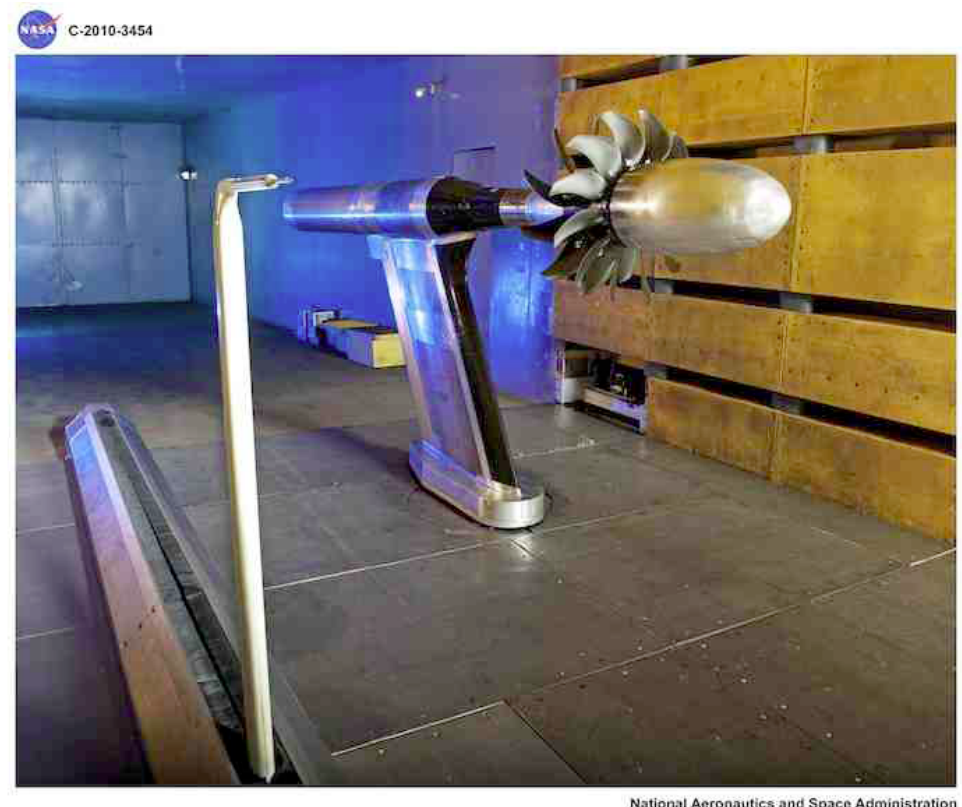

National Aeronautics and Space Administration
Glenn Research Center at Lewis Field

Figure 2.-The open rotor propulsion rig and traversing microphone probe installed in the NASA Glenn 9- by 15-Foot Low-Speed Wind Tunnel.

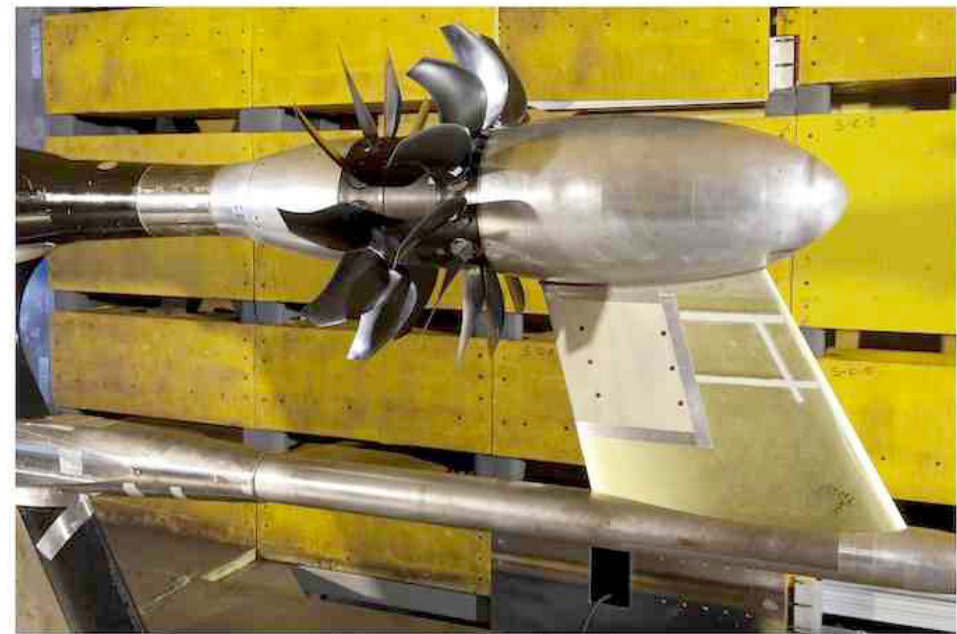

National Aeronautics and Space Administration

Figure 3.-The open rotor propulsion rig installed in the NASA Glenn 9- by 15 -Foot Low-Speed Wind Tunnel with pylon hardware mounted. 
TABLE 1.-THE TEST MATRIX OF TEST SPEEDS RUN FOR THE OPEN ROTOR NASA ENVIRONMENTALLY RESPONSIBLE AVIATION PROJECT IN THE NASA GLENN 9- BY 15-FOOT LOW-SPEED WIND TUNNEL

\begin{tabular}{|c|c|c|c|c|}
\hline $\begin{array}{c}\text { Corrected } \\
\text { Speeds } \\
\text { Tested } \\
\text { (RPM) }\end{array}$ & $\begin{array}{c}\text { Takeoff Pitch - } \\
\text { Pylon }\end{array}$ & $\begin{array}{c}\text { Approach Pitch - } \\
\text { Pylon }\end{array}$ & $\begin{array}{c}\text { Approach Pitch - } \\
\text { Isolated }\end{array}$ & $\begin{array}{l}\text { Takeoff Pitch - } \\
\text { Isolated }\end{array}$ \\
\hline $\begin{array}{c}\text { Mach } 0.2 \\
\text { AOA } 0\end{array}$ & $\begin{array}{c}4628,5561,6080 \\
6316,6450\end{array}$ & $\begin{array}{c}5598,6325,6773 \\
7245,7487\end{array}$ & $\begin{array}{c}5598,6325,6773, \\
7245,7487\end{array}$ & $\begin{array}{c}4628,5277,5561, \\
6080,6316,6450\end{array}$ \\
\hline $\begin{array}{c}\text { Mach } 0.2 \\
\text { AOA } 3\end{array}$ & $4628,5561,6316$ & $5598,6325,6773$ & $5598,6325,6773$ & $4628,5561,6316$ \\
\hline $\begin{array}{c}\text { Mach } 0.2 \\
\text { AOA } 8\end{array}$ & 4628,5561 & $5598,6325,6773$ & $5598,6325,6773$ & $4628,5561,6316$ \\
\hline $\begin{array}{c}\text { Mach } 0.22 \\
\text { AOA } 0\end{array}$ & & $5903,6617,7054$ & $5903,6617,7054$ & $4880,5790,6530$ \\
\hline
\end{tabular}

TABLE 2.-MEASURED GEOMETRIC ANGLES RELATIVE TO THE REAR ROTOR PITCH CHANGE AXIS FOR EACH MICROPHONE TRAVERSING PROBE STOP

\begin{tabular}{|c|c|}
\hline Traversing microphone stop & $\begin{array}{c}\text { Angle, } \\
\text { degrees }\end{array}$ \\
\hline 18 & 17.8 \\
\hline 17 & 22.5 \\
\hline 16 & 30 \\
\hline 15 & 37.5 \\
\hline 14 & 45 \\
\hline 13 & 52.5 \\
\hline 12 & 60 \\
\hline 11 & 67.5 \\
\hline 10 & 75 \\
\hline 9 & 82.5 \\
\hline 8 & 90 \\
\hline 7 & 97.5 \\
\hline 6 & 105 \\
\hline 5 & 112.5 \\
\hline 4 & 120 \\
\hline 3 & 127.5 \\
\hline 2 & 135 \\
\hline 1 & 140.6 \\
\hline & \\
\hline & \\
\hline
\end{tabular}




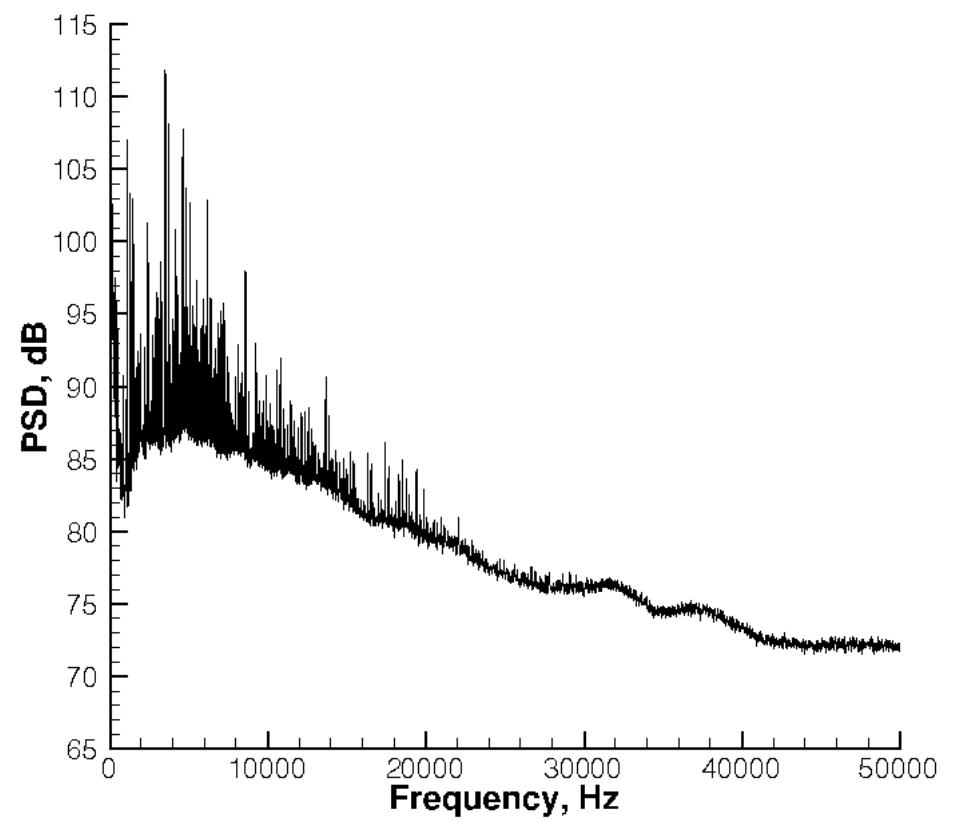

Figure 4.-Power spectrum density of the counter-rotating open rotor historical baseline blades at 6450 corrected rpm with takeoff pitch angle and $141^{\circ}$ relative to the rear rotor pitch change axis.

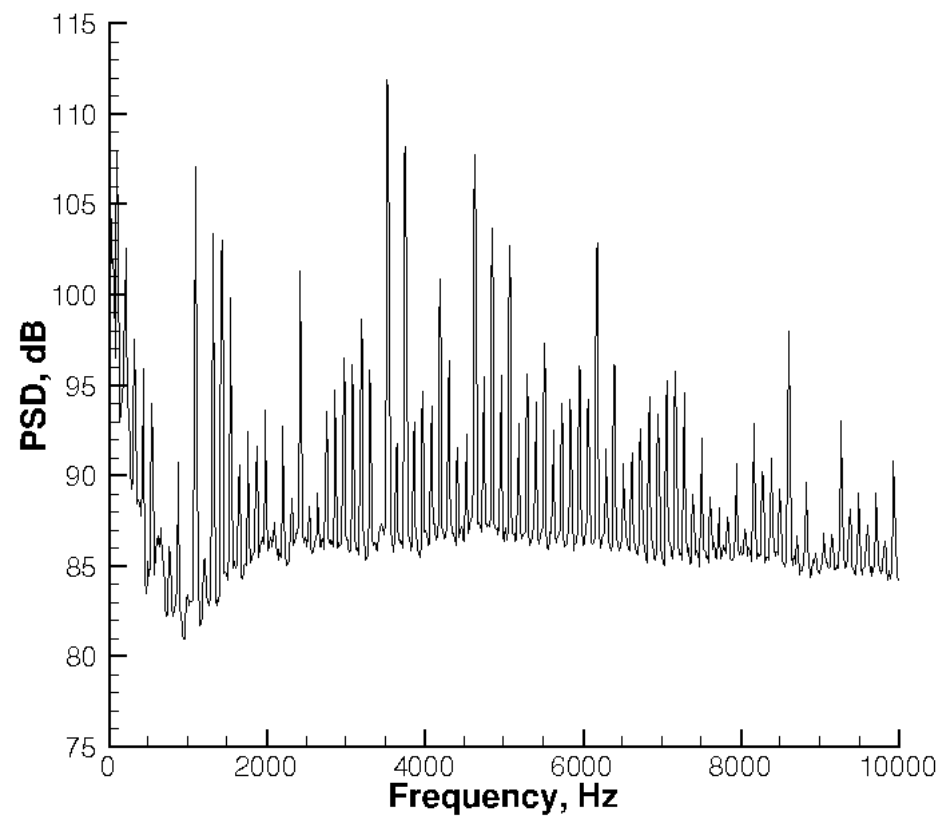

Figure 5.-Power spectrum density from 0 to $10 \mathrm{kHz}$ of the counterrotating open rotor historical baseline blades at 6450 corrected rpm with takeoff pitch angle and $141^{\circ}$ relative to the rear rotor pitch change axis. 


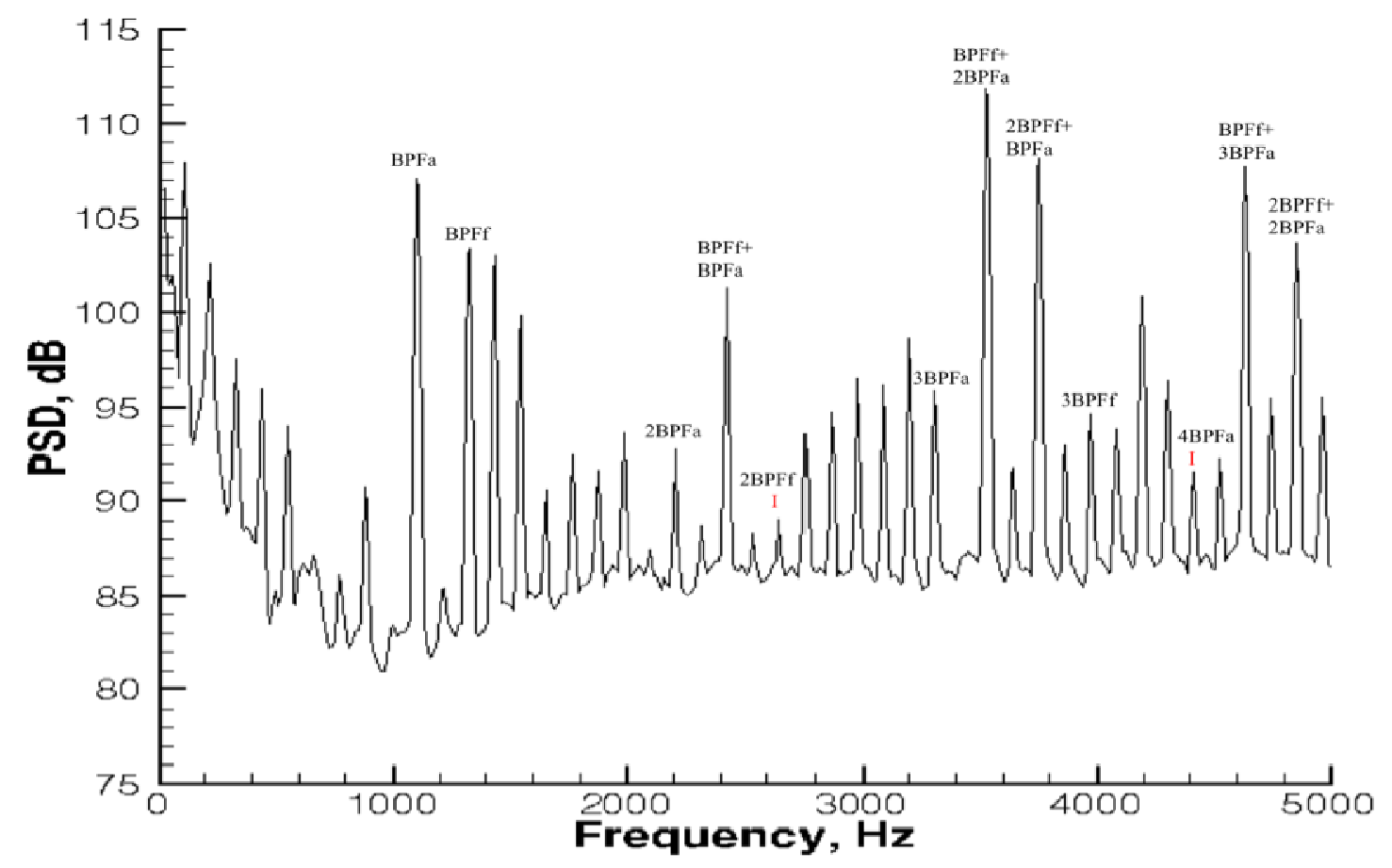

Figure 6.-Power spectrum density from 0 to $5 \mathrm{kHz}$ of the counter-rotating open rotor historical baseline blades at 6450 corrected rpm with takeoff pitch angle and $141^{\circ}$ relative to the rear rotor pitch change axis. blade passage and interaction tones are labeled.

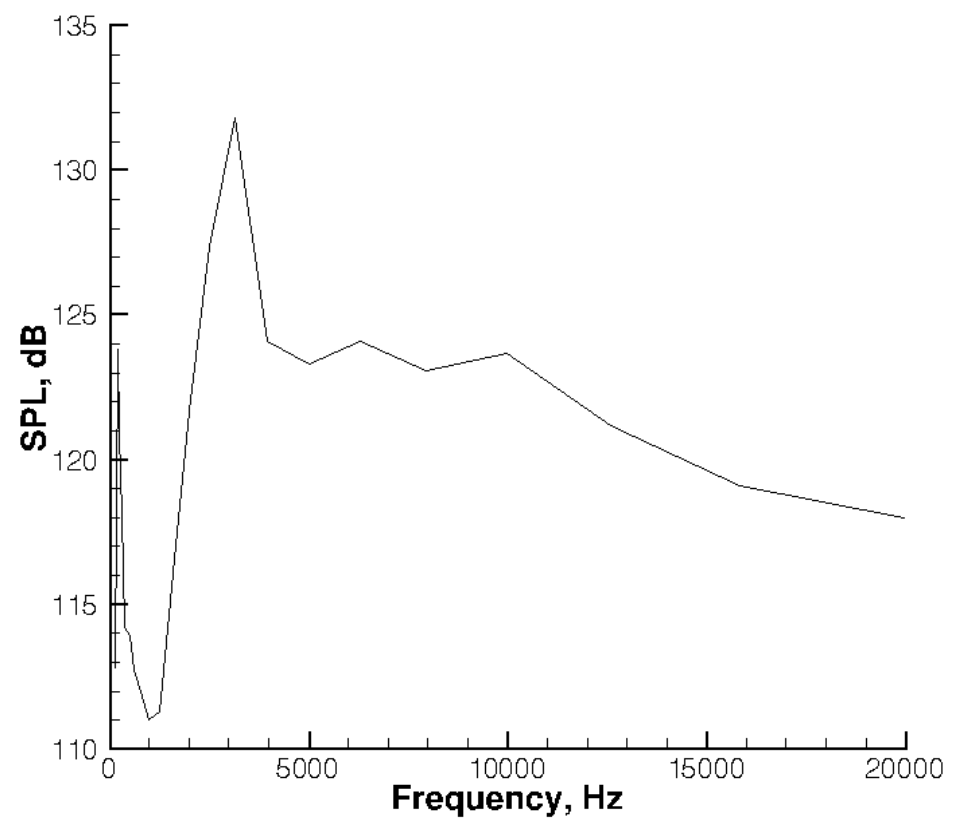

Figure 7.-One-third octave sound pressure level of the counterrotating open rotor historical baseline blades at 6450 corrected rpm with takeoff pitch angle and $141^{\circ}$ relative to the rear rotor pitch change axis. 


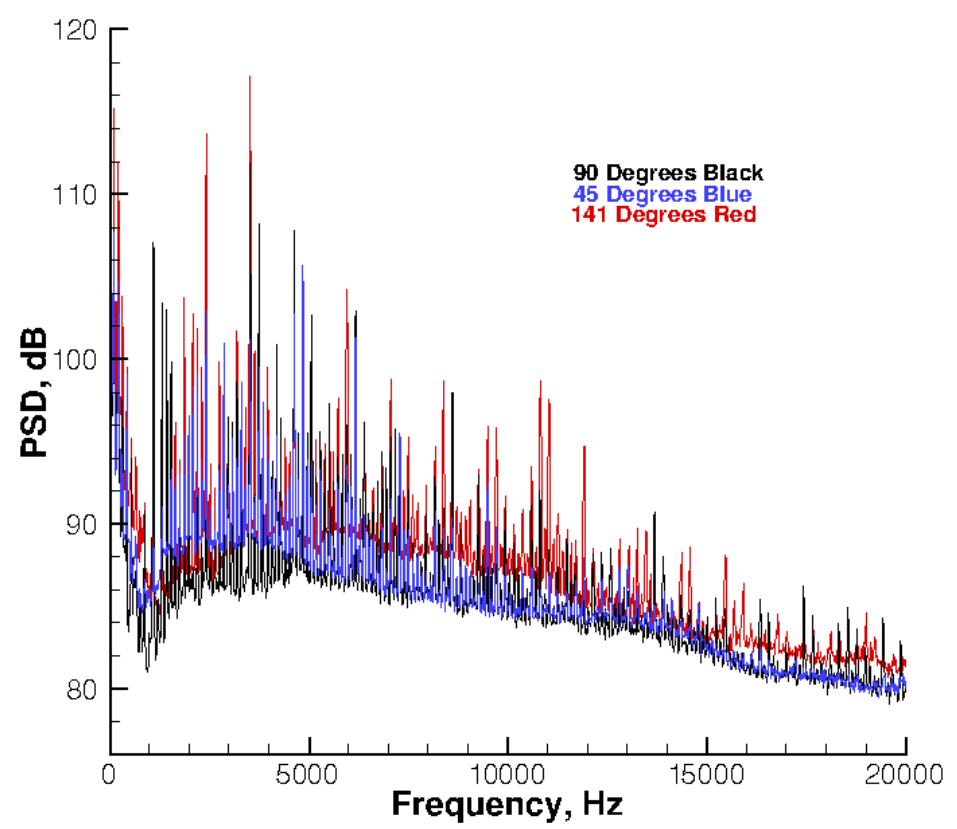

Figure 8.-Power spectrum density showing three different directivity angles relative to the rear rotor pitch change axis for takeoff pitch angle and 6450 corrected rpm.

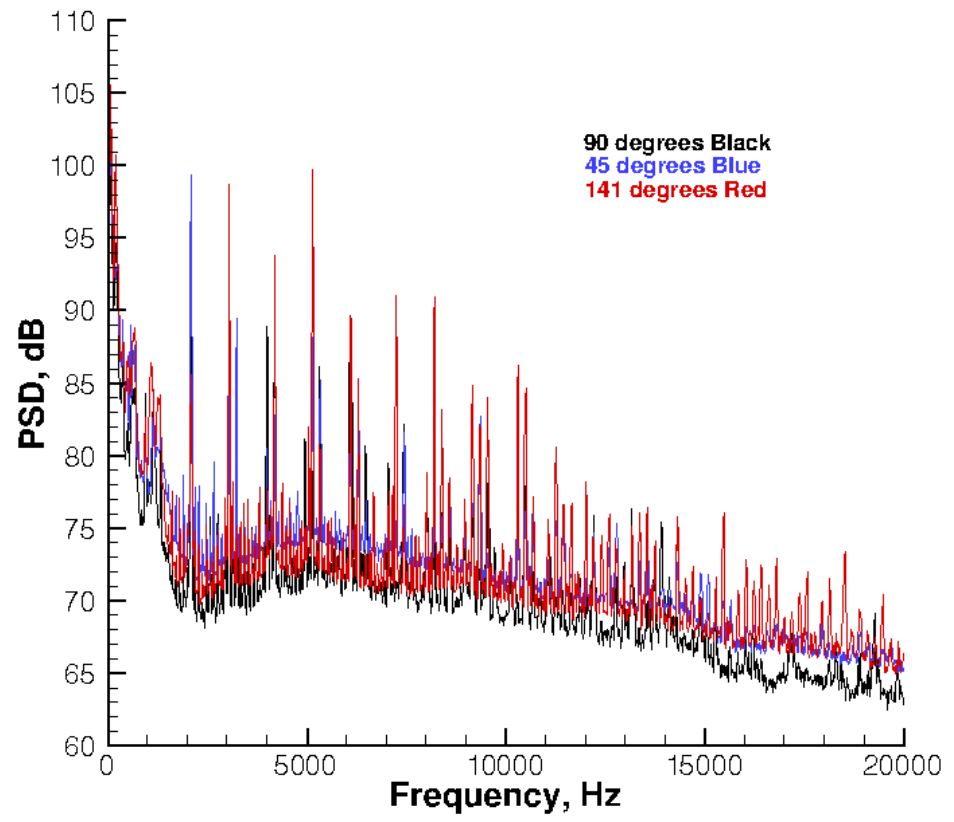

Figure 9.-Power spectrum density showing three different directivity angles relative to the rear rotor pitch change axis for approach pitch angle and 5598 corrected rpm. 


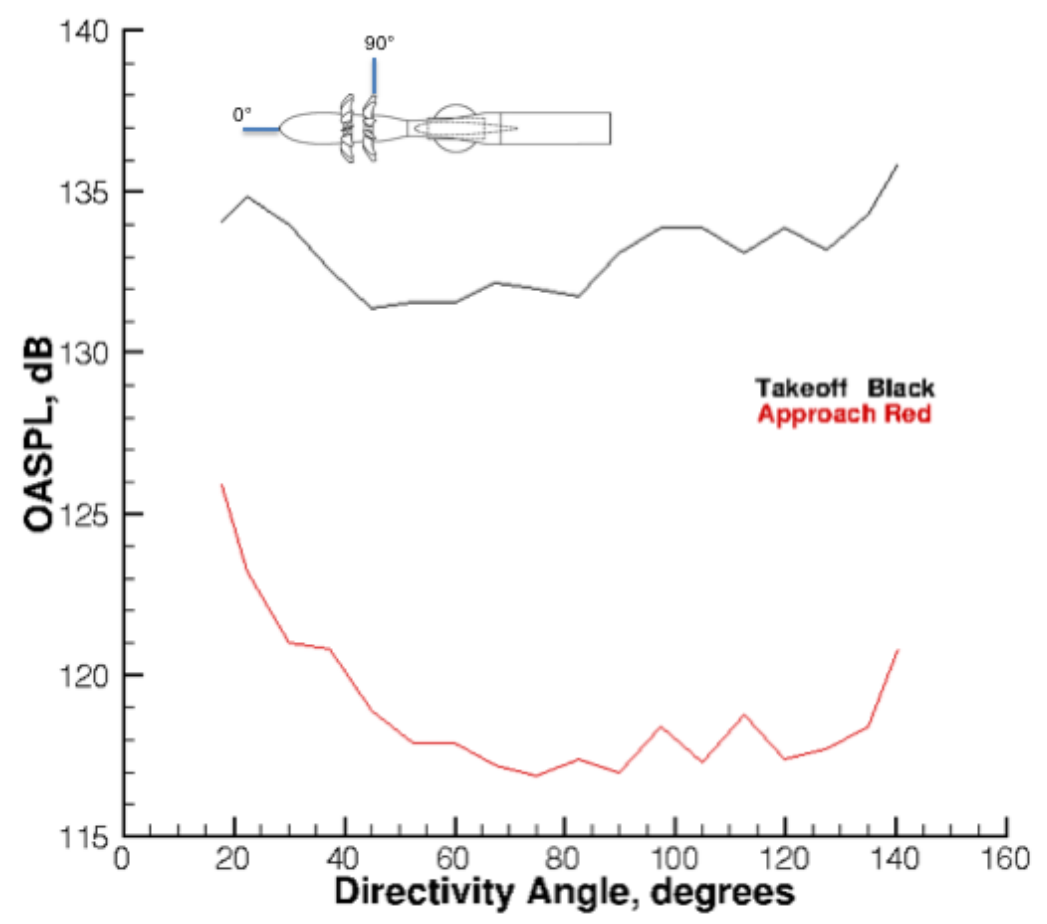

Figure 10.-Overall sound pressure level $(500 \mathrm{~Hz}$ to $50 \mathrm{kHz})$ directivity for approach pitch angle at 5598 corrected rpm and takeoff pitch angle at 6450 corrected rpm. The reference of directivity to the ORPR model is shown in the inset.

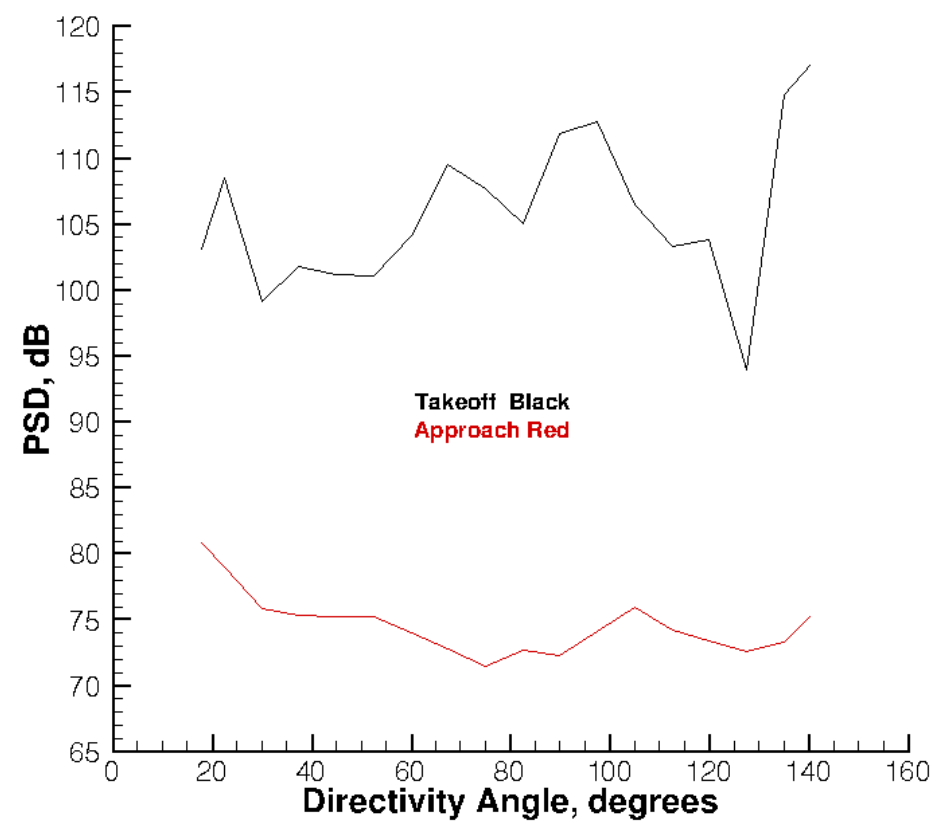

Figure 11.-Power spectrum density directivity of the forward blade passage +2 (Aft blade passage) interaction tone for approach pitch angle at 5598 corrected rpm and takeoff pitch angle at 6450 corrected rpm. 


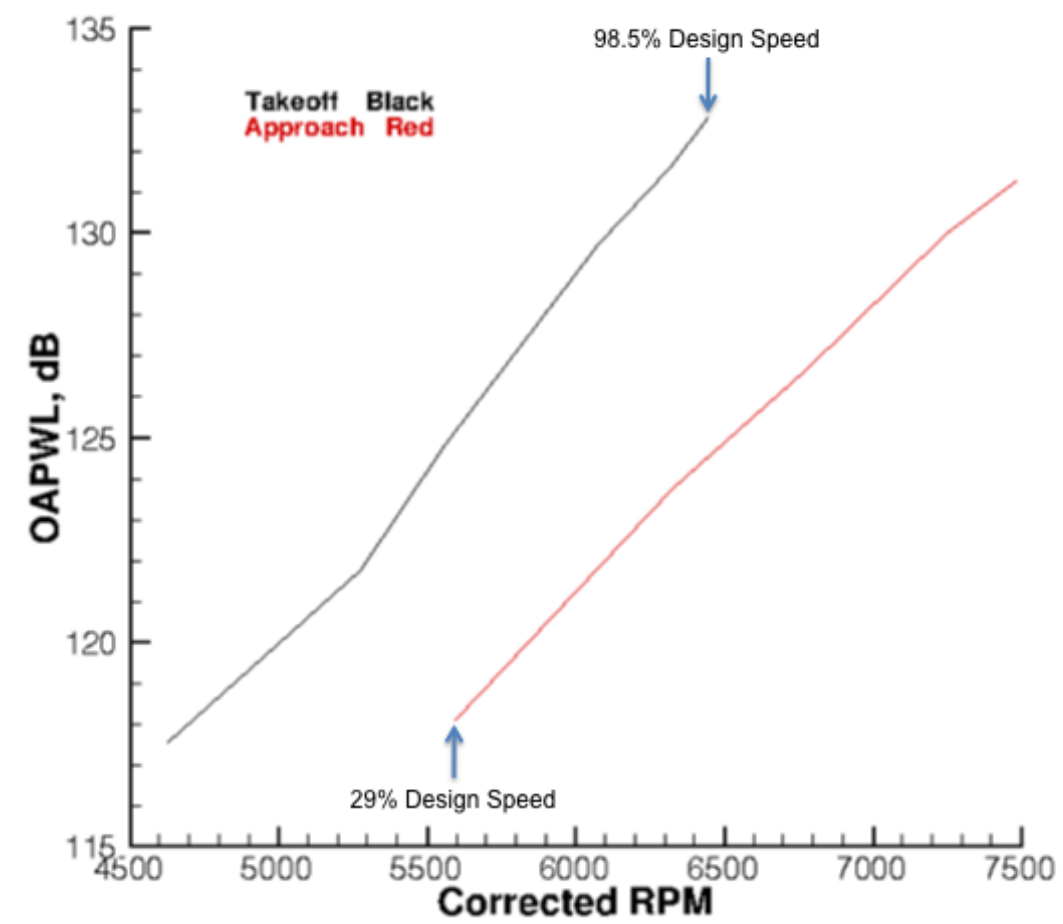

Figure 12.-Overall power levels $(500 \mathrm{~Hz}$ to $50 \mathrm{kHz}$ ) versus corrected rpm of the historical baseline blades for takeoff and approach pitch angles. The 98.5 and 29 percent design speeds are also shown.

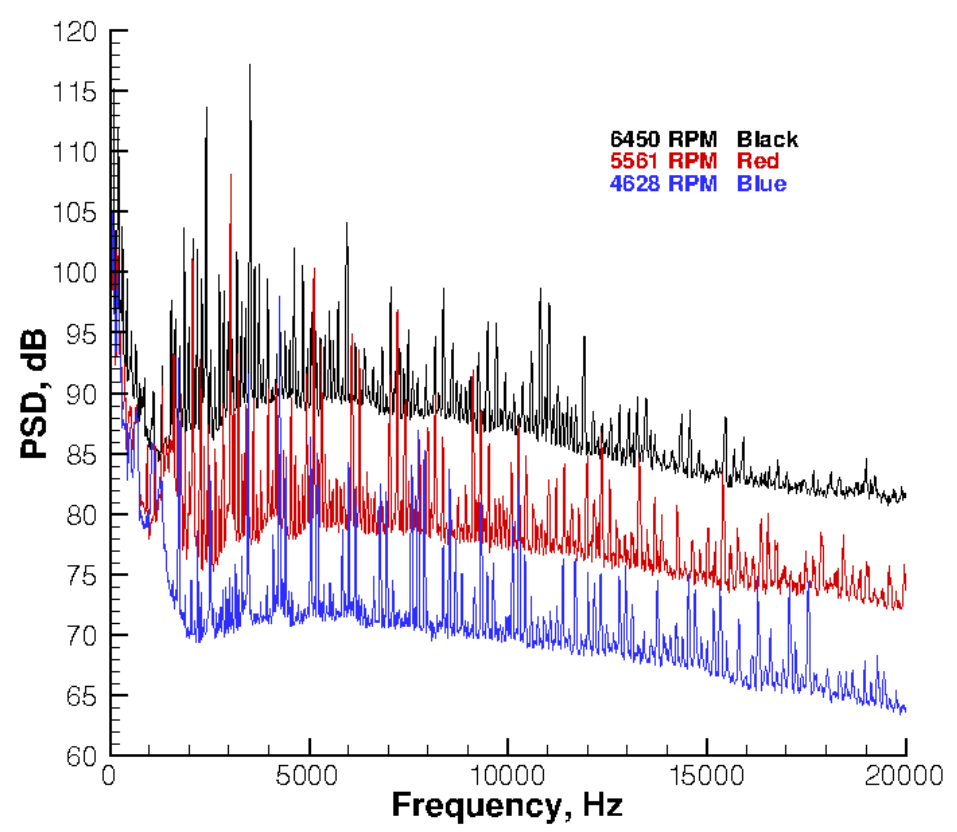

Figure 13.-Power spectrum density for three corrected rpm's of the historical baseline blades at takeoff pitch angle and $141^{\circ}$ relative to the rear rotor pitch change axis. 


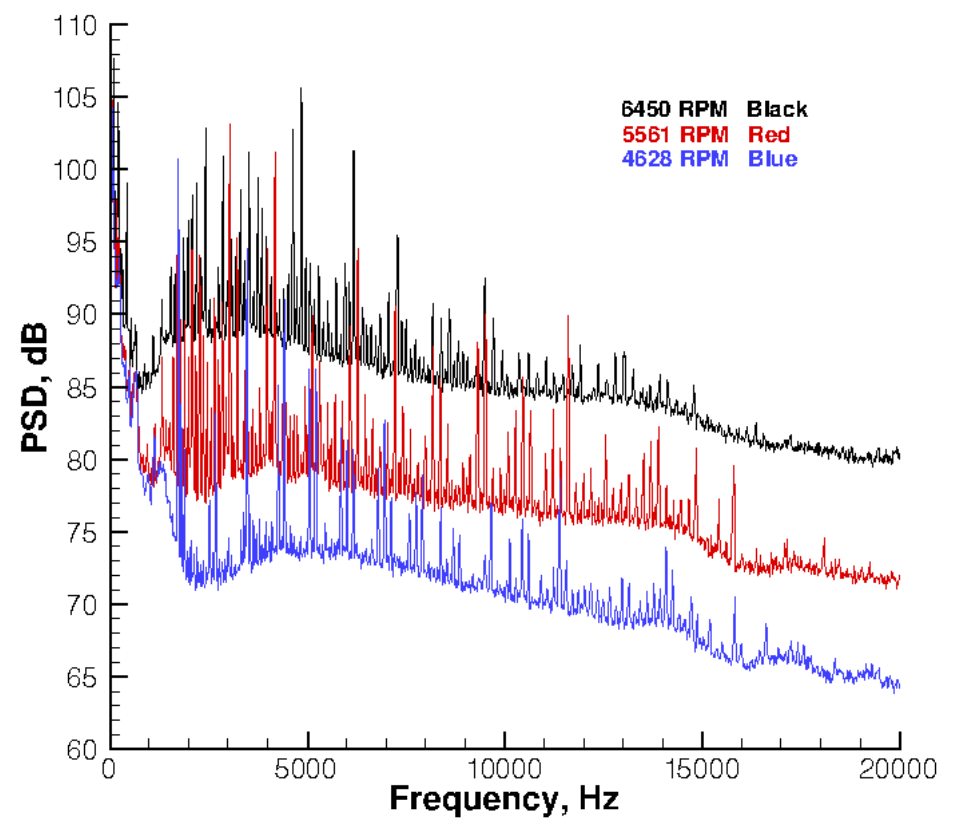

Figure 14.-Power spectrum density for three corrected rpm's of the historical baseline blades at takeoff pitch angle and $45^{\circ}$ relative to the rear rotor pitch change axis.

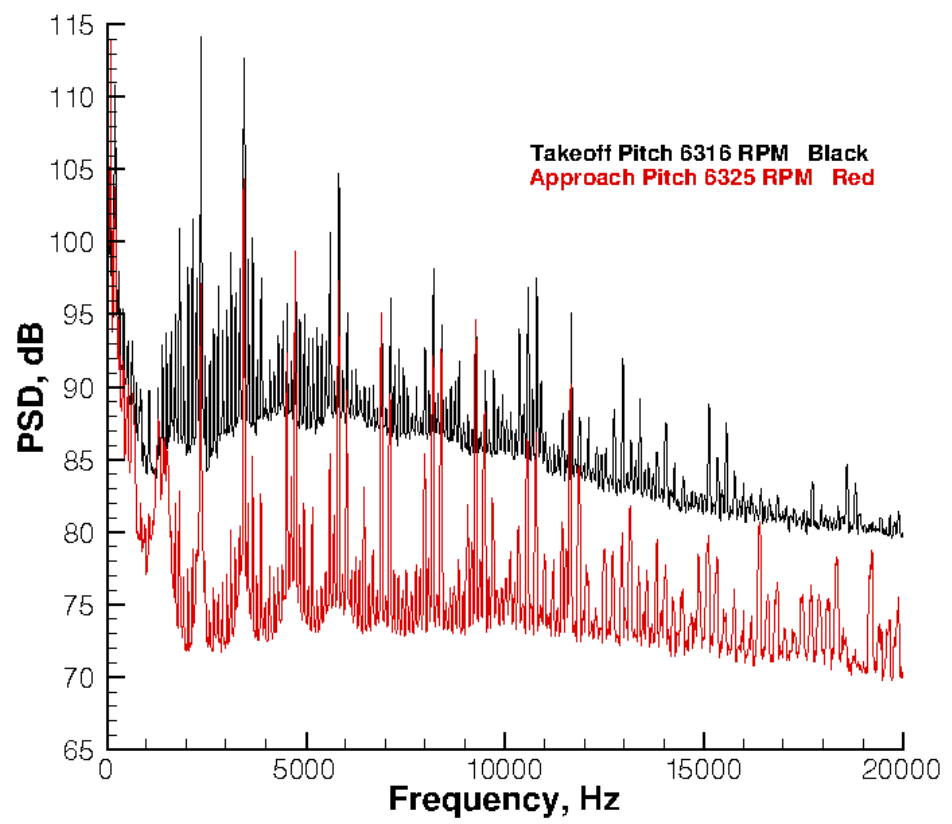

Figure 15.-Power spectrum density comparison of takeoff and approach pitch angles for similar corrected rpm conditions at $141^{\circ}$ relative to the rear rotor pitch change axis. 


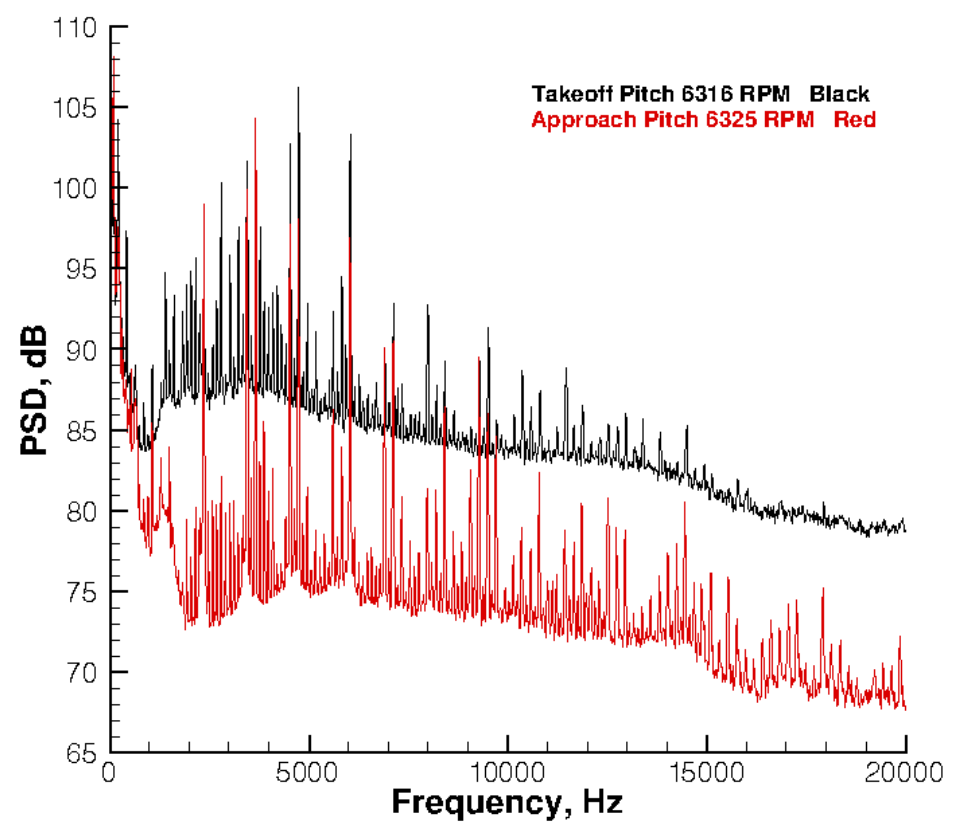

Figure 16.-Power spectrum density comparison of takeoff and approach pitch angles for similar corrected rpm conditions at $45^{\circ}$ relative to the rear rotor pitch change axis.

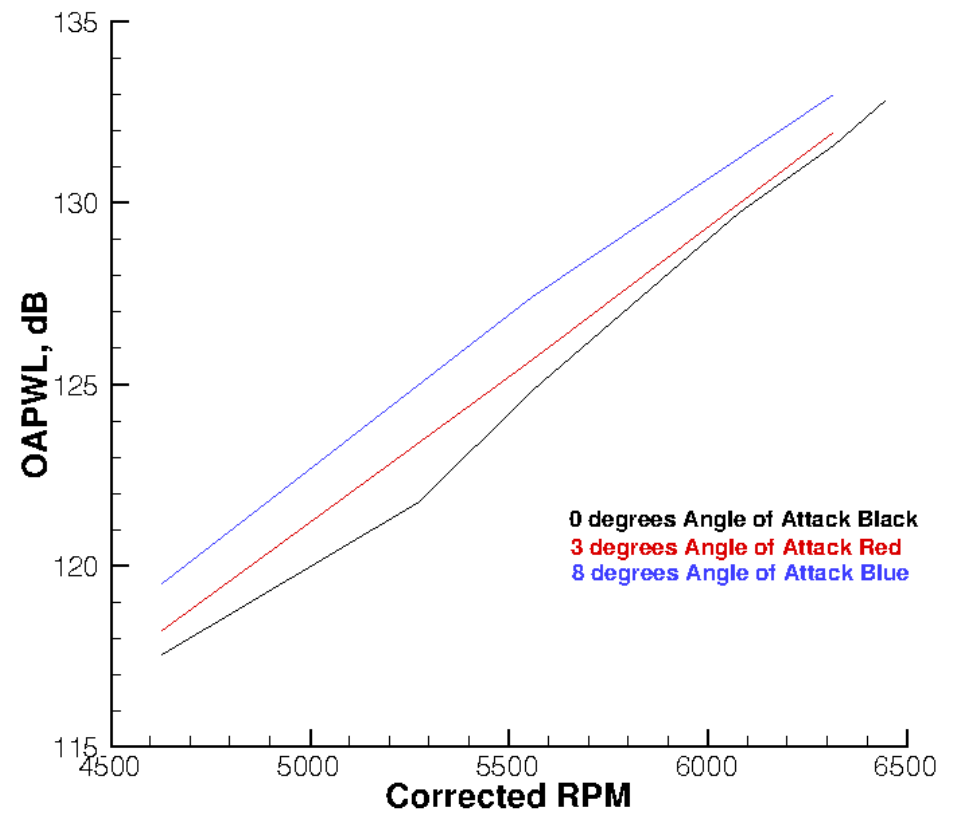

Figure 17.-Overall power levels $(500 \mathrm{~Hz}$ to $50 \mathrm{kHz})$ versus corrected rpm for three angles of attack of the historical baseline blades with takeoff pitch angle. 


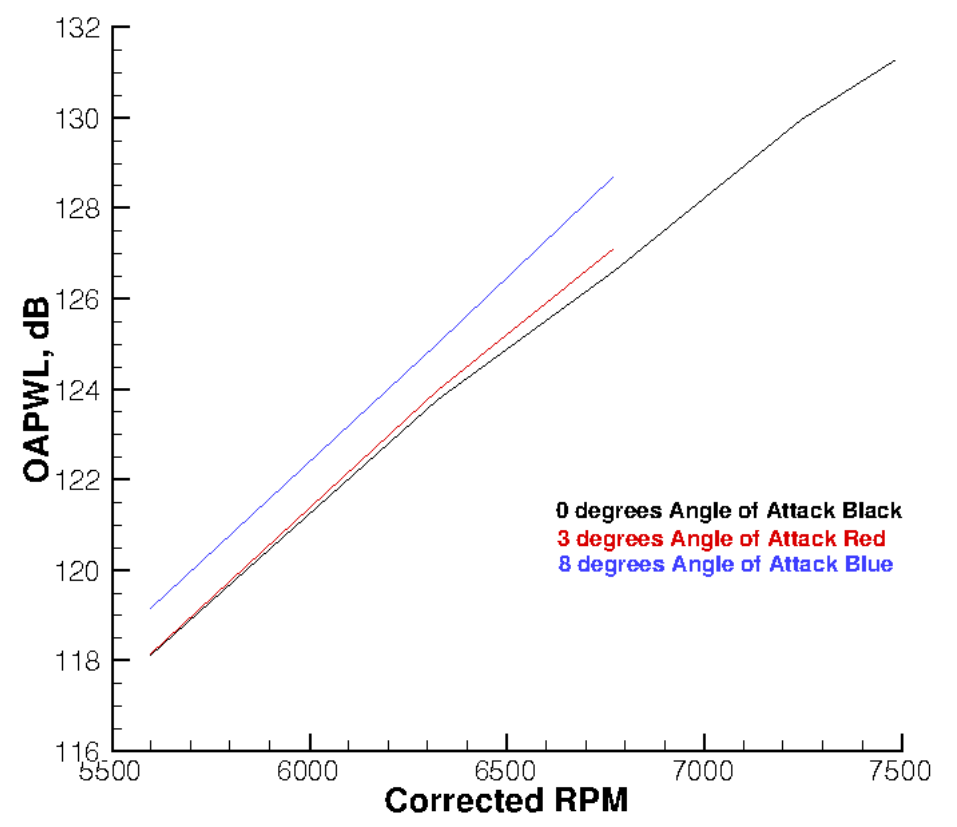

Figure 18.-Overall power levels $(500 \mathrm{~Hz}$ to $50 \mathrm{kHz})$ versus corrected rpm for three angles of attack of the historical baseline blades with approach pitch angle.

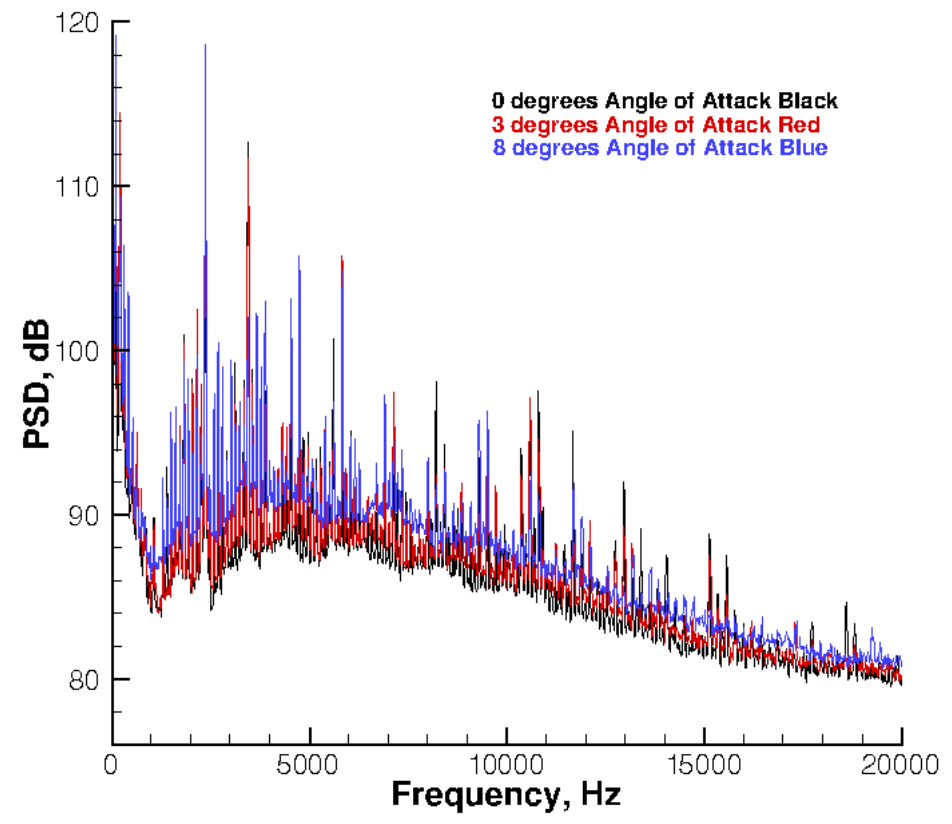

Figure 19.-Power spectrum density of the historical baseline blades for three angles of attack at takeoff pitch angle, 6316 corrected $\mathrm{rpm}$, and $141^{\circ}$ relative to the rear rotor pitch change axis. 


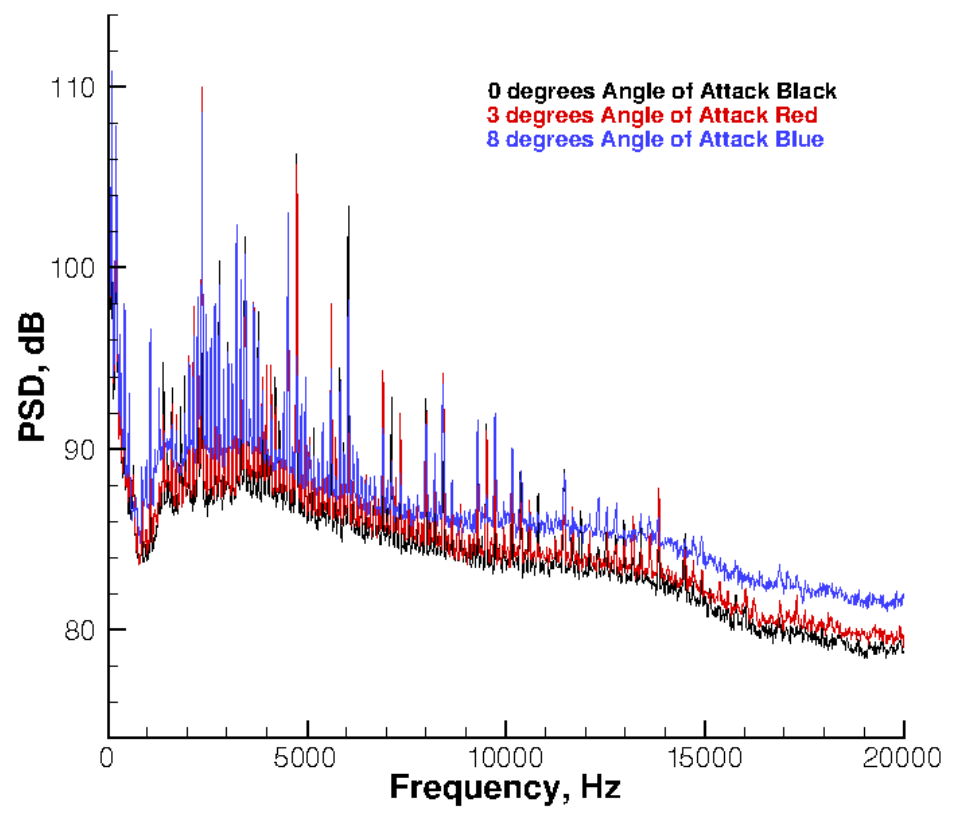

Figure 20.--Power spectrum density of the historical baseline blades for three angles of attack at takeoff pitch angle, 6316 corrected $\mathrm{rpm}$, and $45^{\circ}$ relative to the rear rotor pitch change axis.

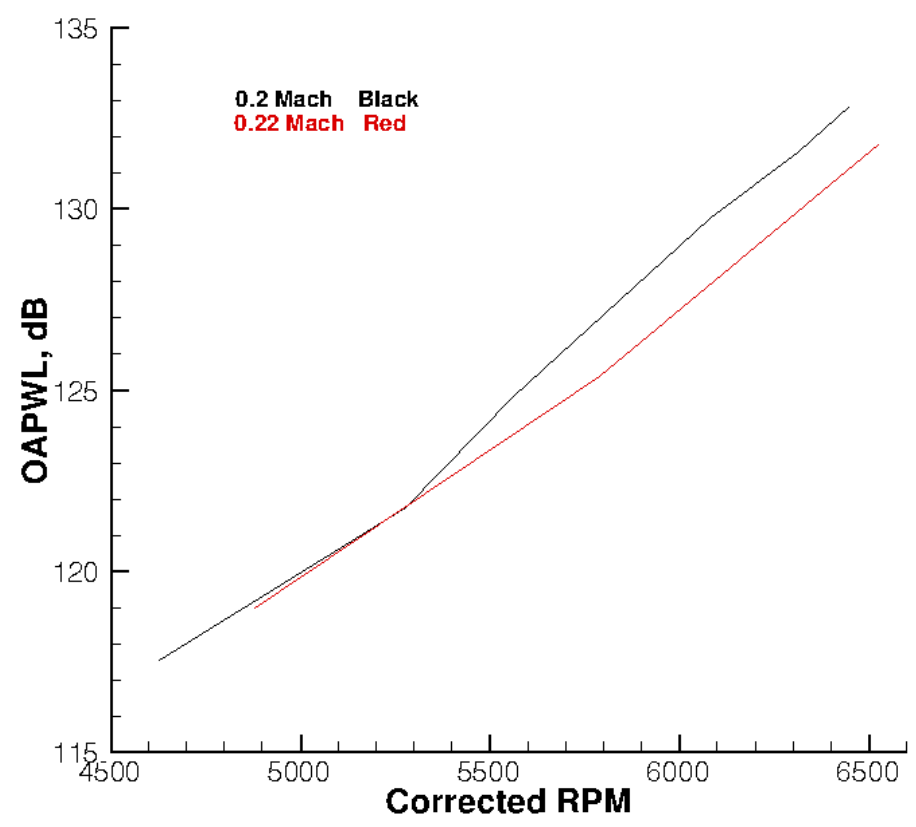

Figure 21.-O Overall Power Level $(500 \mathrm{~Hz}$ to $50 \mathrm{kHz})$ versus corrected rpm of Historical Baseline Blades for two free flow Mach numbers and takeoff pitch angle. The rpm was adjusted for 0.22 Mach to match condition. 


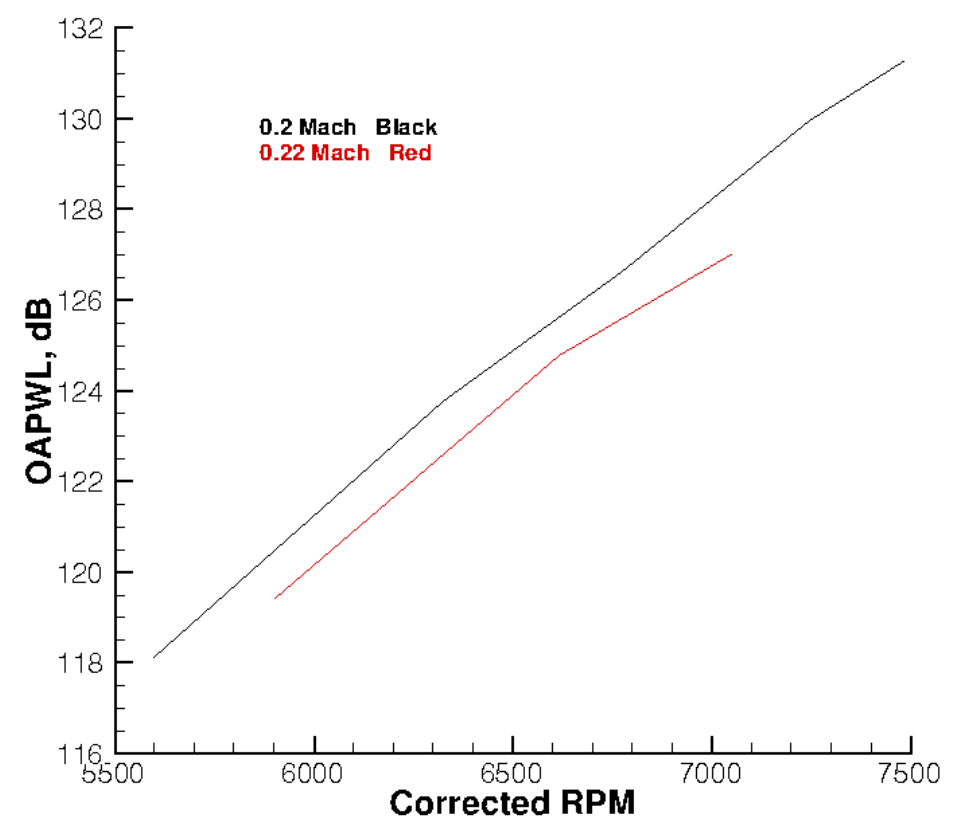

Figure 22.-O Overall power level $(500 \mathrm{~Hz}$ to $50 \mathrm{kHz}$ ) versus corrected rpm of historical baseline blades for two free flow Mach numbers and approach pitch angle. The rpm was adjusted for 0.22 Mach to match condition.

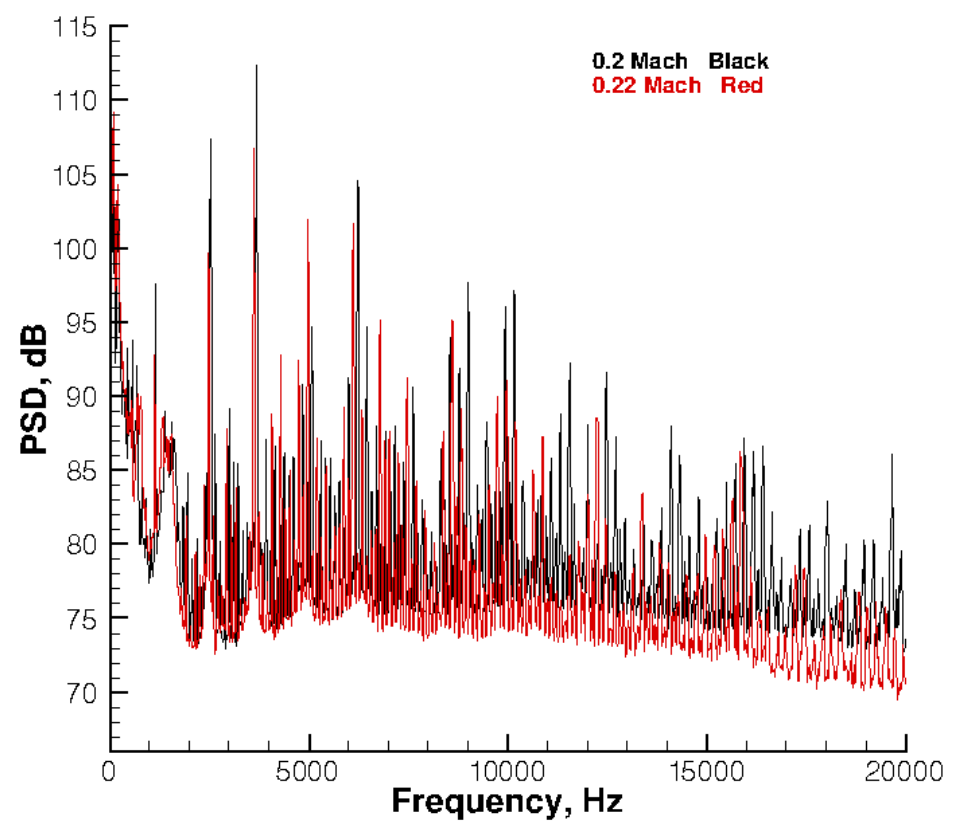

Figure 23.-Power spectrum density of historical baseline blades for two free flow Mach numbers at approach pitch angle and $141^{\circ}$ relative to rear rotor pitch change axis. The rpm was 6773 for Mach 0.2 and 6617 for Mach 0.22. 


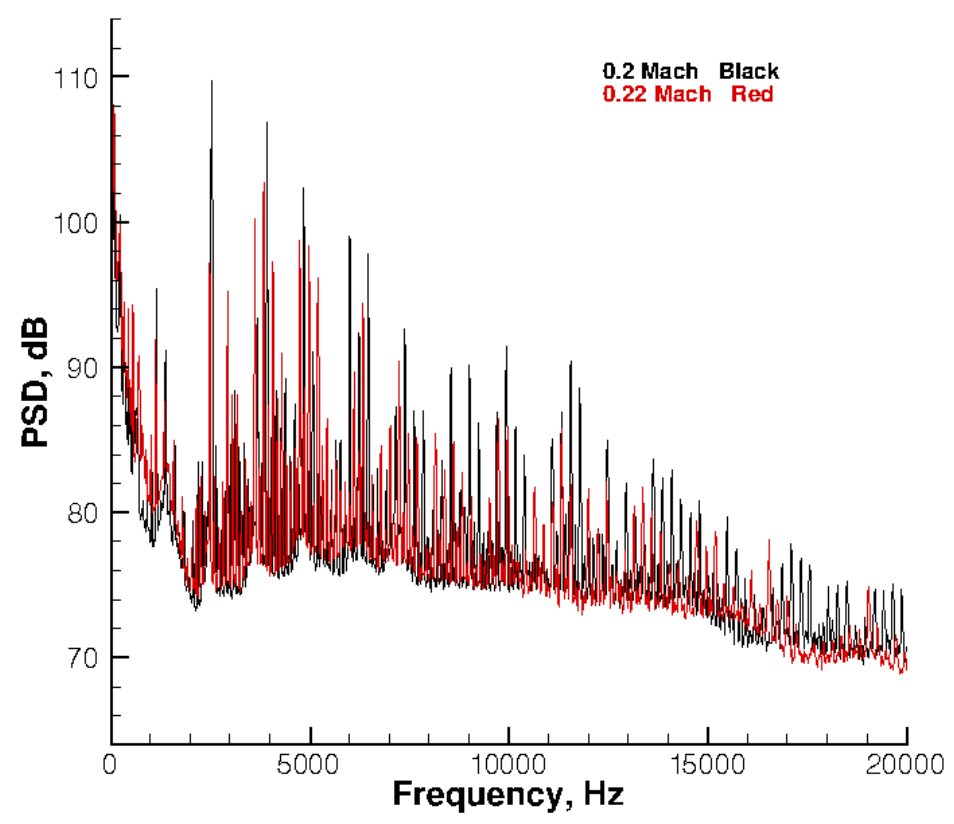

Figure 24.-Power spectrum density of historical baseline blades for two free flow Mach numbers at approach pitch angle and $45^{\circ}$ relative to rear rotor pitch change axis. The rpm was 6773 for Mach 0.2 and 6617 for Mach 0.22.

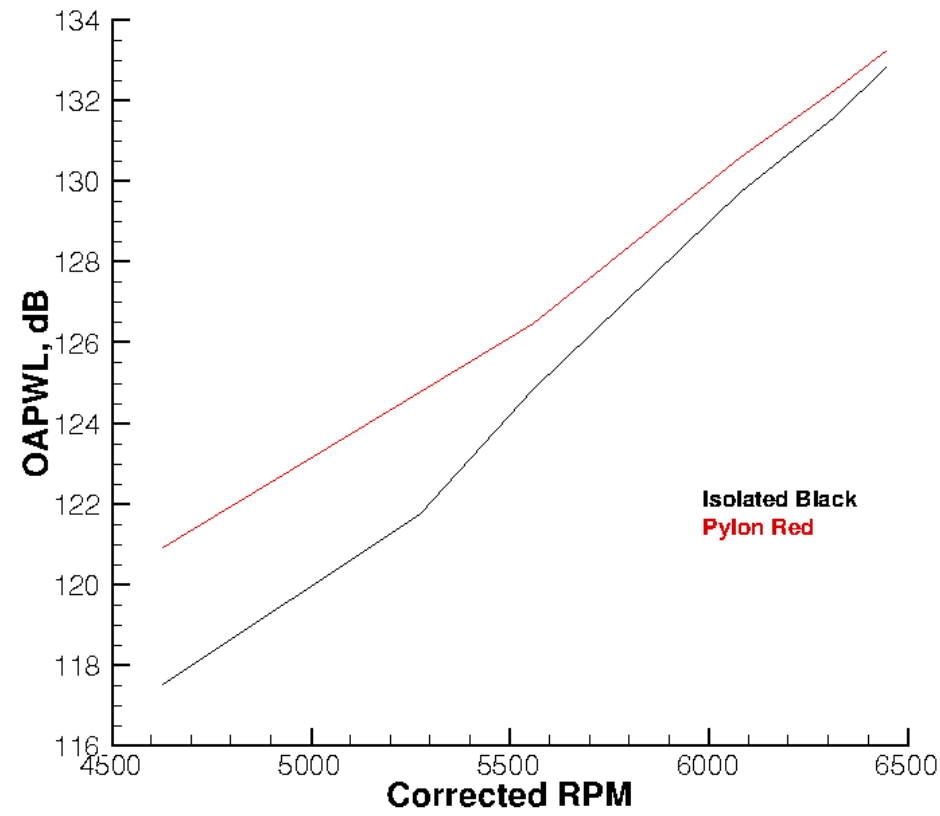

Figure 25.-Overall power level $(500 \mathrm{~Hz}$ to $50 \mathrm{kHz})$ versus corrected rpm of historical baseline blades for isolated and pylon configurations at takeoff pitch angle. 


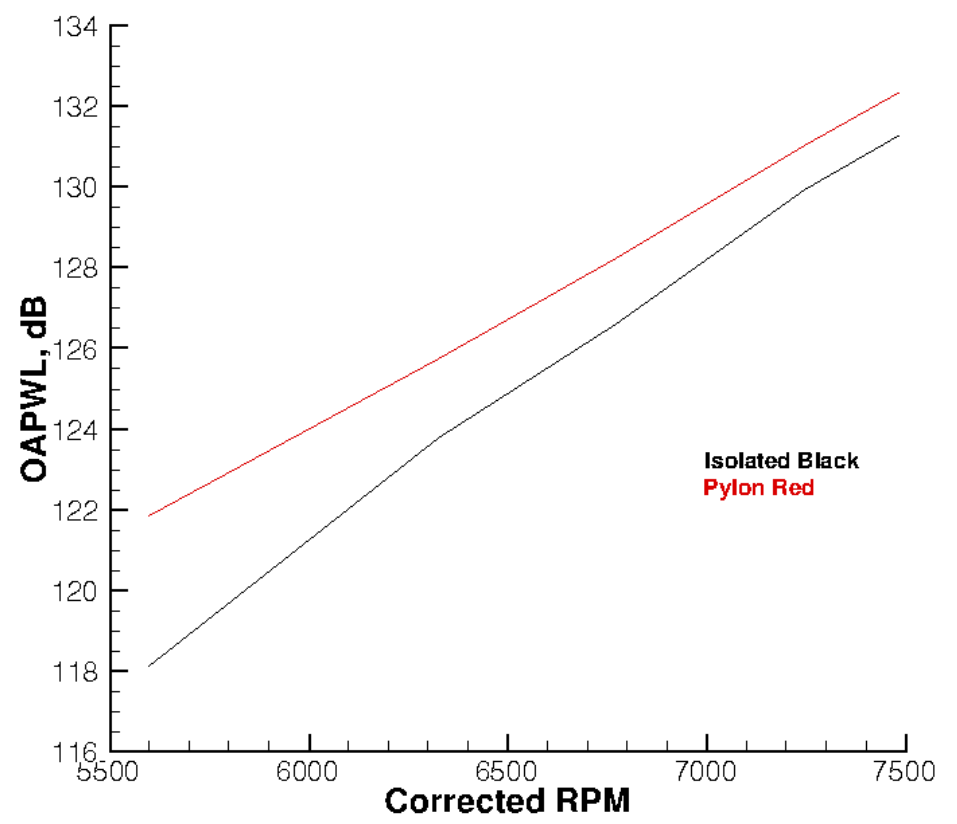

Figure 26.-Overall power level $(500 \mathrm{~Hz}$ to $50 \mathrm{kHz})$ versus corrected rpm of historical baseline blades for isolated and pylon configurations at approach pitch angle.

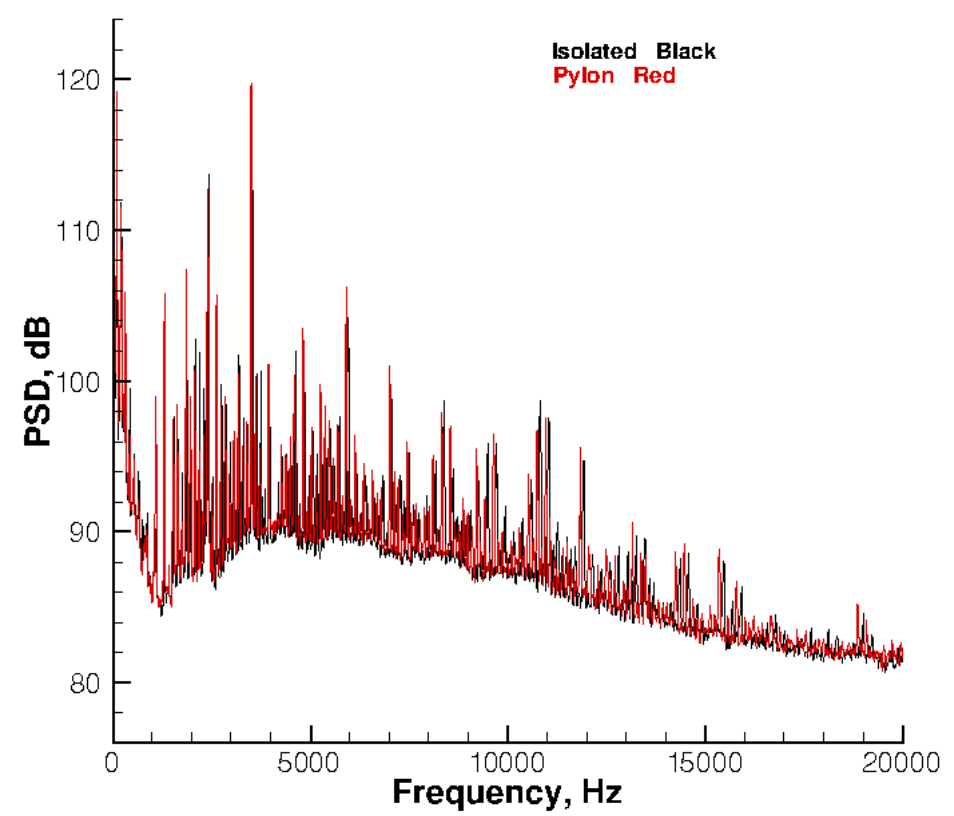

Figure 27.-Power spectrum density of historical baseline blades for isolated and pylon configurations at takeoff pitch angle, 6450 corrected rpm, and $141^{\circ}$ relative to rear rotor pitch change axis. 


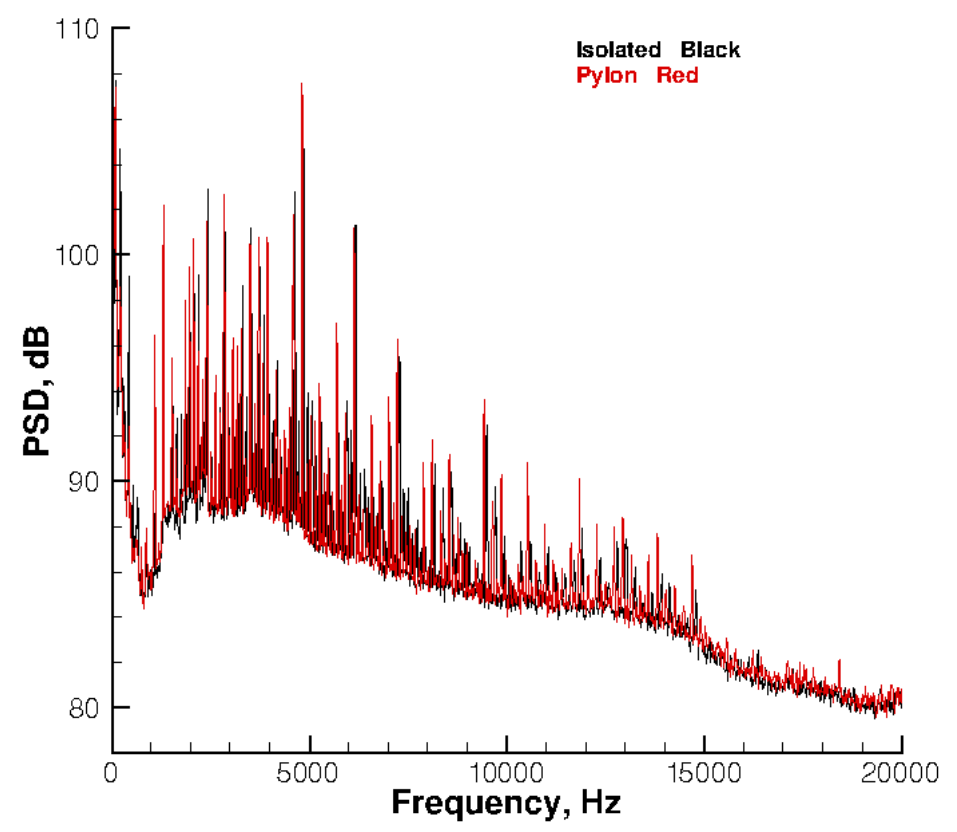

Figure 28.-Power spectrum density of historical baseline blades for isolated and pylon configurations at takeoff pitch angle, 6450 corrected rpm, and $45^{\circ}$ relative to rear rotor pitch change axis.

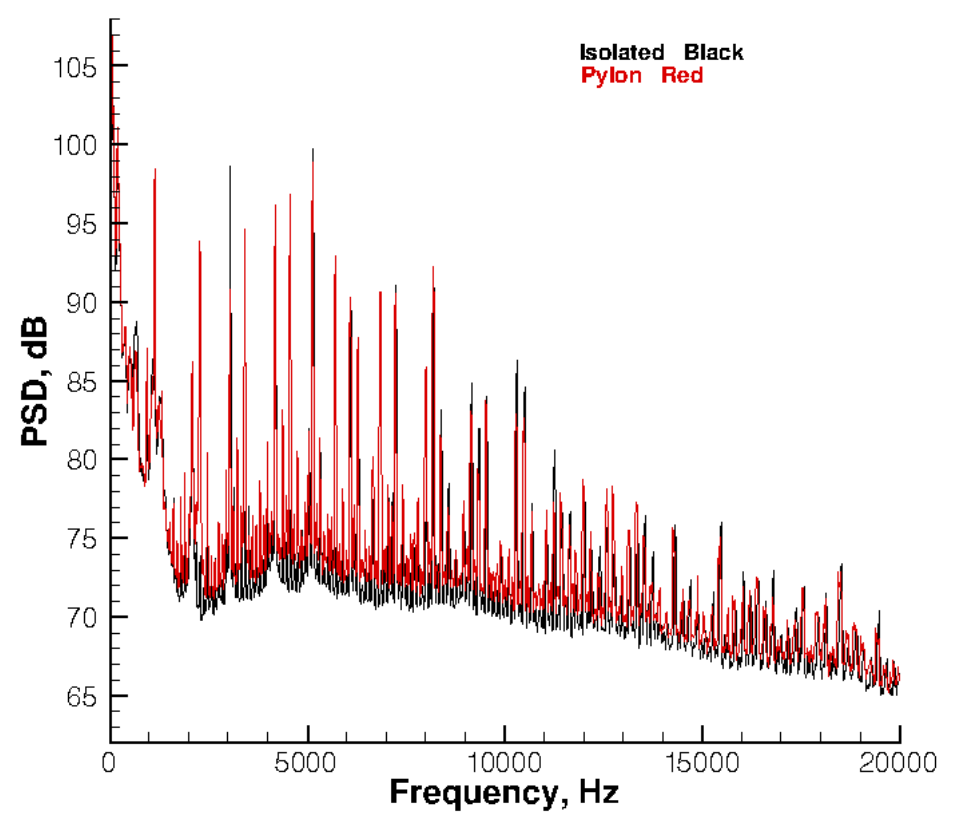

Figure 29.--Power spectrum density of historical baseline blades for isolated and pylon configurations at approach pitch angle, 5598 corrected rpm, and $141^{\circ}$ relative to rear rotor pitch change axis. 


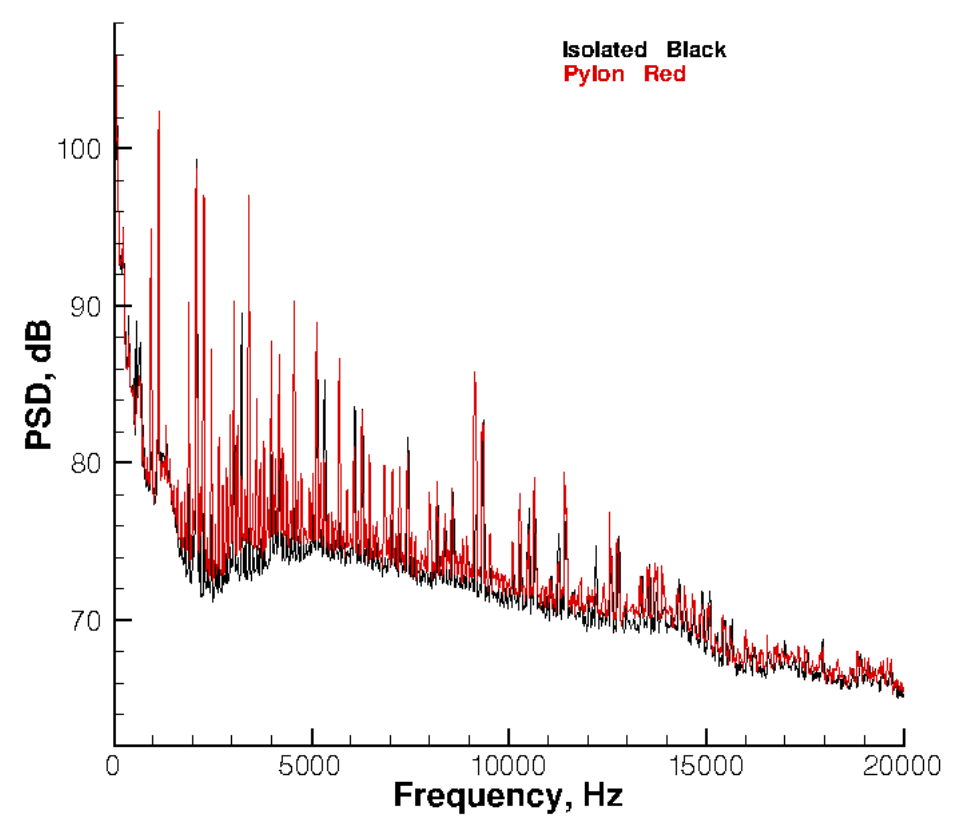

Figure 30.-Power spectrum density of historical baseline blades for isolated and pylon configurations at approach pitch angle, 5598 corrected $\mathrm{rpm}$, and $45^{\circ}$ relative to rear rotor pitch change axis.

\section{References}

1. Woodward, R.P., "Noise of a Model High Speed Counter-rotation Propeller at Simulated Takeoff/Approach Conditions (F7/A7),” NASA TM-100206, Oct. 1987.

2. Woodward, R.P., Hall, D.G., Podboy, G.G., and Jeracki, R.J., "Takeoff/Approach Noise for a Model Counter-rotation Propeller with a Forward-Swept Upstream Rotor,” AIAA-93-0596, presented at the $31^{\text {st }}$ Aerospace Sciences Meeting \& Exhibit, Reno, NV, January 11-14, 1993.

3. Van Zante, Dale E., Gazzaniga John A., Elliott, David M., and Woodward, Richard P., "An Open Rotor Test Case: F31/A31 Historical Baseline Blade Set,” ISABE-2011-1310, 2011, to be published.

4. Dahl, M.D., and Woodward, R.P., "Comparison Between Design and Installed Acoustic Characteristics of the NASA Lewis 9-by 15-Foot Low-Speed Wind Tunnel Acoustic Treatment," NASA TP-2996, Apr. 1990.

5. Dahl, M.D., and Woodward, R.P., "Background Noise Levels Measured In the NASA Lewis 9- by 15-Foot Low-Speed Wind Tunnel,” NASA TP-3274, Nov. 1992.

6. Woodward, R.P., and Dittmar, J.H., "Background Noise Levels Measured in the NASA Lewis 9- by 15- Foot Low-Speed Wind Tunnel,” NASA TM-106817/AIAA-95-0720, 1995. 


\begin{tabular}{|c|c|c|c|c|c|}
\hline \multicolumn{5}{|c|}{ REPORT DOCUMENTATION PAGE } & $\begin{array}{l}\text { Form Approved } \\
\text { OMB No. 0704-0188 }\end{array}$ \\
\hline \multicolumn{6}{|c|}{ 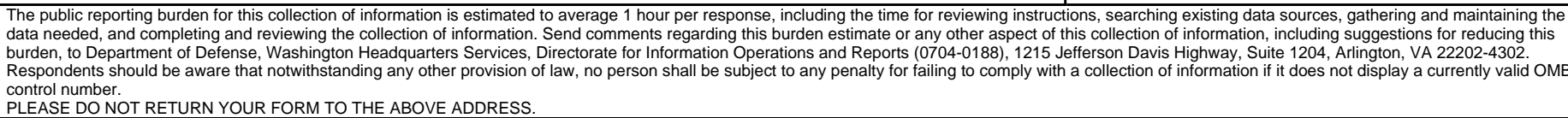 } \\
\hline \multicolumn{2}{|c|}{$\begin{array}{l}\text { 1. REPORT DATE (DD-MM-YYYY) } \\
01-03-2012\end{array}$} & \multicolumn{3}{|c|}{$\begin{array}{l}\text { 2. REPORT TYPE } \\
\text { Technical Memorandum }\end{array}$} & 3. DATES COVERED (From - To) \\
\hline \multirow{3}{*}{\multicolumn{5}{|c|}{$\begin{array}{l}\text { 4. TITLE AND SUBTITLE } \\
\text { Initial Investigation of the Acoustics of a Counter-Rotating Open Rotor Model With } \\
\text { Historical Baseline Blades in a Low-Speed Wind Tunnel }\end{array}$}} & 5a. CONTRACT NUMBER \\
\hline & & & & & 5b. GRANT NUMBER \\
\hline & & & & & 5c. PROGRAM ELEMENT NUMBER \\
\hline \multirow{3}{*}{\multicolumn{5}{|c|}{$\begin{array}{l}\text { 6. AUTHOR(S) } \\
\text { Elliott, David, M. }\end{array}$}} & 5d. PROJECT NUMBER \\
\hline & & & & & 5e. TASK NUMBER \\
\hline & & & & & $\begin{array}{l}\text { 5f. WORK UNIT NUMBER } \\
\text { WBS 699959.02.09.03.05 }\end{array}$ \\
\hline \multicolumn{5}{|c|}{$\begin{array}{l}\text { 7. PERFORMING ORGANIZATION NAME(S) AND ADDRESS(ES) } \\
\text { National Aeronautics and Space Administration } \\
\text { John H. Glenn Research Center at Lewis Field } \\
\text { Cleveland, Ohio 44135-3191 }\end{array}$} & $\begin{array}{l}\text { 8. PERFORMING ORGANIZATION } \\
\text { REPORT NUMBER } \\
\text { E-18013 }\end{array}$ \\
\hline \multirow{2}{*}{\multicolumn{5}{|c|}{$\begin{array}{l}\text { 9. SPONSORING/MONITORING AGENCY NAME(S) AND ADDRESS(ES) } \\
\text { National Aeronautics and Space Administration } \\
\text { Washington, DC 20546-0001 }\end{array}$}} & $\begin{array}{l}\text { 10. SPONSORING/MONITOR'S } \\
\text { ACRONYM(S) } \\
\text { NASA }\end{array}$ \\
\hline & & & & & $\begin{array}{l}\text { 11. SPONSORING/MONITORING } \\
\text { REPORT NUMBER } \\
\text { NASA/TM-2012-217258 }\end{array}$ \\
\hline \multicolumn{6}{|c|}{$\begin{array}{l}\text { 12. DISTRIBUTION/AVAILABILITY STATEMENT } \\
\text { Unclassified-Unlimited } \\
\text { Subject Category: } 71 \\
\text { Available electronically at http://www.sti.nasa.gov } \\
\text { This publication is available from the NASA Center for AeroSpace Information, 443-757-5802 }\end{array}$} \\
\hline \multicolumn{6}{|c|}{ 13. SUPPLEMENTARY NOTES } \\
\hline \multicolumn{6}{|c|}{$\begin{array}{l}\text { 14. ABSTRACT } \\
\text { A counter-rotating open rotor scale model was tested in the NASA Glenn Research Center 9- by 15-Foot Low-Speed Wind Tunnel (LSWT). } \\
\text { This model used a historical baseline blade set with which modern blade designs will be compared against on an acoustic and aerodynamic } \\
\text { performance basis. Different blade pitch angles simulating approach and takeoff conditions were tested, along with angle-of-attack } \\
\text { configurations. A configuration was also tested in order to determine the acoustic effects of a pylon. The shaft speed was varied for each } \\
\text { configuration in order to get data over a range of operability. The freestream Mach number was also varied for some configurations. } \\
\text { Sideline acoustic data were taken for each of these test configurations. }\end{array}$} \\
\hline \multicolumn{6}{|c|}{$\begin{array}{l}\text { 15. SUBJECT TERMS } \\
\text { Acoustics; Counter rotating; Open rotor blades; Baseline blades }\end{array}$} \\
\hline \multicolumn{3}{|c|}{ 16. SECURITY CLASSIFICATION OF: } & $\begin{array}{l}\text { 17. LIMITATION OF } \\
\text { ABSTRACT }\end{array}$ & $\begin{array}{l}\text { 18. NUMBER } \\
\text { OF }\end{array}$ & $\begin{array}{l}\text { 19a. NAME OF RESPONSIBLE PERSON } \\
\text { STI Help Desk (email:help@sti.nasa.gov) }\end{array}$ \\
\hline $\begin{array}{l}\text { a. REPORT } \\
\text { U }\end{array}$ & $\begin{array}{l}\text { b. ABSTRACT } \\
\text { U }\end{array}$ & $\begin{array}{l}\text { c. THIS } \\
\text { PAGE } \\
\text { U }\end{array}$ & UU & $\begin{array}{c}\text { PAGES } \\
28\end{array}$ & $\begin{array}{l}\text { 19b. TELEPHONE NUMBER (include area code) } \\
443-757-5802\end{array}$ \\
\hline
\end{tabular}


